GEOFIZIKA VOL. $37 \quad 2020$

DOI: https://doi.org/10.15233/gfz.2020.37.5

Original scientific paper

\title{
Assessing vulnerability for inhabitants of Dhaka City considering flood-hazard exposure
}

\author{
Md. Enamul Huq ${ }^{1}$, Qimin Cheng*2, Orhan Altan ${ }^{3}$, A. Z. M. Shoeb ${ }^{4}$, Mallik \\ Akram Hossain ${ }^{5}$, Md. Nazirul Islam Sarker ${ }^{6}$, Nayyer Saleem ${ }^{1}$, Akib Javed ${ }^{1}$, \\ Xiaoyi Longg ${ }^{7}$, Ahmed Abdullah Al Dughairi ${ }^{8}$, Md. Masud Parves Rana ${ }^{4}$, \\ Abdullah Al Mamun ${ }^{9}$ and Md. Mahabubur Rahman ${ }^{10}$ \\ ${ }^{1}$ State key Laboratory for Information Engineering in Surveying, Mapping and Remote \\ Sensing, Wuhan University, Wuhan, China \\ ${ }^{2}$ School of Electronics Information and Communications, Huazhong University \\ of Science and Technology, Wuhan, China \\ ${ }^{3}$ Department of Geomatics, Istanbul Technical University, Istanbul, Turkey \\ ${ }^{4}$ Department of Geography and Environmental Studies, University of Rajshahi, \\ Rajshahi, Bangladesh \\ ${ }^{5}$ Department of Geography and Environment, Jagannath University, Dhaka, Bangladesh \\ ${ }^{6}$ School of Political Science and Public Administration, Neijiang Normal University, \\ Sichuan, China \\ ${ }^{7}$ School of Computer, Wuhan University, Wuhan, China \\ ${ }^{8}$ Department of Geography, Faculty of Arabic Language and Social Studies, Qassim University, \\ Qassim Burydah, Kingdom of Saudi Arabia \\ ${ }^{9}$ Department of Mechanical Manufacturing Engineering, School of Mechanical and Automotive \\ Engineering, South China University of Technology, Guangzhou, Guangdong, China \\ ${ }^{10}$ Department of Computer Science and Engineering, Bangladesh University \\ of Business and Technology, Dhaka, Bangladesh
}

Received 27 February 2020, in final form 4 August 2020

Global flood hazard is gradually increasing. Though it is impossible to avoid them, losses and damage of hazards (e.g., floods, cyclones, and earthquakes) could be efficiently reduced by reducing household vulnerability with appropriate measures. This study aims to quantitatively measure the household vulnerability of flood hazards as a mitigation tool. It also proposed a unique approach to quantify flood-hazard household vulnerability, and shows its application in the flood prone city of Dhaka as an example case. Data were collected from both slum and non-slum areas to cover the entire urban habitat, and to compare their level of flood vulnerability. A total of 300 households were surveyed by structured questionnaire on the basis of five factors (economic, social, environmental, 
structural, and institutional) of flood vulnerability. The analytical hierarchy process (AHP) was applied to measure individual household vulnerability scores by using the relative weightage of variables and indicators with proper standardisation. Analytical results demonstrated that $63.06 \%$ slum and $20.02 \%$ non-slum households were highly vulnerable to floods. In addition, this paper determined and assessed responsible factors for household flood vulnerability in Dhaka. For structural vulnerability, results exhibited that $82 \%$ of slum households were highly vulnerable, and $95.3 \%$ of non-slum households were moderately vulnerable. Socially, $67.3 \%$ of slum and $78.7 \%$ of non-slum households were moderately and low-vulnerable. The majority of slum and non-slum households (84\% and 59.3\%, respectively) showed high and moderate vulnerability with respect to economic vulnerability. Moreover, $69.3 \%$ of slum and $65.3 \%$ of nonslum household institutional vulnerability levels were high. Of slum inhabitants, $63.3 \%$ were environmentally at high risk, and $78 \%$ of non-slum habitats were in the low-vulnerability category. However, as an effective tool to measure location-specific vulnerability, it is applicable for the measuring vulnerability of other cities in the world with proper customisation. On the basis of this study, future research could be conducted with more factors, variables, and indicators of human vulnerability to natural or artificial hazards/disasters. Future work may provide a better reflection of the vulnerability status of single/multiple hazard(s)/disaster(s).

Keywords: flood hazard, quantifying vulnerability, AHP, urban inhabitants, Bangladesh

\section{Introduction}

The impact of natural disasters is severe/increases due to the vulnerability of the general population (Halgamuge and Nirmalathas, 2017). The physical damage of natural hazards has dramatically increased in the last few decades, globally affecting people. In 2019, almost 409 disaster events and roughly 11,000 fatalities caused by disasters were globally reported. The Asia Pacific belt faced the most disasters probably because of its geographical location and susceptibility. Most fatalities were caused by earthquakes, cyclones, floods, tsunamis, heat, tropical bushfires, and droughts (Aliperti et al., 2019). The recent climate change has also impacted disaster frequency. It raises the risk of extreme weather, and results in the increased occurrence of floods and droughts. Moreover, it enhances storm power, for example, tropical cyclones. Indian rainy-season floods were the deadliest calamity in 2019 with about 1750 casualties. Hydrological hazards (floods, cyclones, tsunamis) affected the greatest number of people in the previous decade, with 2019 ranked as the 11th costliest catastrophe year in the 21st century (Khlopov, 2019). However, approximately $47 \%$ of weather-associated disasters occurred in 1995-2015 due to floods, affecting 2.3 billion people with 157,000 deaths (Atreya et al., 2017). In 2016, floods killed almost 4731 people and affected 78.1 million people (Guha-Sapir et al., 2016). In addition, 5624 (CRED, 2018) and 2859 (UNISDR, 2019) people died because of floods in 2017 and 2018 , respectively. Around $80 \%$ out of the entire global population are affected by riverine floods every year in the 15 least developed and/or developing 
nations in Asia, Africa, and the Americas. Regrettably, extreme floods are very frequent and destructive in Europe. In addition, since 1995, the duration and magnitude of affected regions have increased. However, floods globally interrupt physical and socioeconomic circumstances, including in Bangladesh (Parvin and Johnson, 2015; Rahaman, 2018), India (Halgamuge and Nirmalathas, 2017), China (Huang et al., 2012), Vietnam (Vu and Ranzi, 2017), South Africa (Dalu et al., 2017), Mexico (Atreya et al., 2017), Indonesia (Azmeri et al., 2016), Myanmar (Brakenridge et al., 2017), the UK (Coles et al., 2017), Canada (PattisonWilliams et al., 2018), the Czech Republic (Duží et al., 2017), Spain (Hooke, 2016), France (Montané et al., 2017), Japan (Nakanishi and Black, 2018), Pakistan (Tariq and van de Giesen, 2012), and Algeria (Yamani et al., 2016). Because of disasters, low-income families that are already struggling could be pushed into poverty because of having fewer resources, few diversified earning sources, and the lack of sufficient financial protection (Samanta et al., 2018). However, investigations of disaster preparedness before flood events could help to mitigate the adverse consequences of flood disasters, and can be cost-effective over time.

Bangladesh is a flood prone country. Floods are as a constant phenomenon in both rural and urban areas, including in Dhaka, the capital of Bangladesh, and its adjoining areas (Rahaman, 2018; Sciance and Nooner, 2018). According to EM-DAT (2014), approximately twenty million people in Bangladesh live with flood risk. Capital and megacity Dhaka is threatened by severe flood hazards (Azad et al., 2013). The overwhelming growth of the urban poor, and the presence of numerous slums and squats in Dhaka accelerates the severity of flood hazards (BBS, 2016). Low-income opportunities, dilapidated housing conditions, and slum locations are considered to be major determinants of flood vulnerability in Dhaka (Huang et al., 2012). However, slum dwellers are frequently characterised by the lowest level of education and low economic status. The reality is that poor people tend to live in high-risk zones, which makes them vulnerable to epidemics and flood-related disasters (Schneiderbauer and Ehrlich, 2006). Insufficient resources, inappropriate planning, rapid urban growth, and growing populations increase the vulnerability of urban residents for coping with disasters (Rahaman, 2018). Findings from various studies showed that floods caused extensive damage to infrastructures such as roads, housing, and water supply. It was estimated that a 1998 flood displaced about 94\% of families in Dhaka, and the total flood-affected population was 4.55 million (Huq and Alam, 2003; Nayyer et al., 2019). Moreover, floods recently extensively damaged built infrastructures, which puts urban people in Dhaka in a vulnerable situation (Pilli-Sihvola et al., 2018; Shao et al., 2020).

However, there are few studies (Alam and Rabbani, 2007; Barua et al., 2016) focused on index-based socioeconomic, institutional, structural, and environmental vulnerability measurements with a weighted index, particularly in Dhaka, Bangladesh. However, Hung et al. (2016) did notable work related to household vulnerability in the USA that applied principal-component analysis (PCA) to 
discover the spatial variations of household vulnerability to the storm surge in Sarasota, Florida. Shah et al. (2020) investigated household vulnerability to flooding and related public-health problems in disaster-prone areas of Pakistan. Very recently, Solín et al. (2018) qualitatively assessed household vulnerability to flood hazards in the Myjava basin in Slovakia, and discussed the likelihood of vulnerability reduction in the existing flood-risk management framework. Despite that, many extensive qualitative, but few quantitative, studies on household vulnerability to flood hazards were done. Moreover, no comparative investigation for slum and non-slum residents has been carried out. Therefore, this study identifies responsible factors for creating household vulnerability to flood hazards for urban inhabitants (both slum and non-slum). The core objectives of the present study were to (i) develop a vulnerability index (VI) to measure household flood vulnerability and assess the comparative vulnerability level; and (ii) compare the level of vulnerability between slum and non-slum inhabitants. The scientific contribution of the paper is a unique method to measure household flood vulnerability. This method can quantify household vulnerability to both natural and artificial disasters. The quantification of household vulnerability is another scientific contribution of this study, as most previous studies explained vulnerability qualitatively. Moreover, the application of the proposed vulnerability index methodological framework bridges qualitative and quantitative vulnerability measurement.

\section{Conceptualisation and literature review}

\subsection{Profiling and defining vulnerability}

Vulnerability perception is an influential analytical tool to describe the damage-susceptibility level, and weakness for physical and social systems. It also guides the normative investigation of actions for enhancing wellbeing through disaster-risk reduction (DRR). It is mostly conceptualised as components that comprise exposure and sensitivity to perturbations, external pressure, and adaptation capacity (Ligon and Schechter, 2003). Vulnerabilities mostly come from insecurity insights. Two notable hazard studies successfully bridged the work by Blaikie et al. (1994) and the pressure-and-release (PAR) hazard model. The model put forward that physical and/or biological hazards denote pressure and features of vulnerability. Then, another type of pressure originates from increasing vulnerability progression, and root causes by local geography and social distinction. These two pressure types come to head during disasters resultant from extra hazard and vulnerability pressure. Vulnerability represents an attribute of the socioecological system that, besides seeking to elaborate the combination of mechanisms and processes, illustrates a conceptual model in analysis. Furthermore, an approach developed by Turner et al. (2003) sought to analyse vulnerability components (e.g., exposure, sensitivity, and resilience) in a confined system on a specific spatial scale. 
Natural disasters damage lives, assets, and livelihoods, and create vulnerability in society. Vulnerability refers the system of a community's physical, social, economic, and political exposure to damage resulting from hazardous events (Cardona, 2011). Vulnerability in disaster management is very complex and varied, particularly for flood management. To clearly understand the notion of vulnerability requires a clear conception of vulnerability, and its elements and factors. It could be understood on the individual and household level. Though vulnerability was defined differently in previous studies, it generally refers to the susceptibility of a community that suffered from an event, often determined by the community's geographical exposure (Barua et al., 2016; Dewan, 2013; Samanta et al., 2018; Sarker et al., 2020). In addition, the vulnerability level of certain communities depends on different factors, like physical, institutional, social, political, demographical, and economic. However, to make vulnerability meaningful, a deeper understanding of it is needed. Vulnerability is also often "discovered" after the event, for example, various disaster-related studies found that most victims come from vulnerable groups. Disaster specialists developed several explanations of vulnerability. For example, social scientists claim that vulnerability refers to a set of socioeconomic aspects that determine people's capacity to deal with stress. However, climate scientists pose that vulnerability depends on occurrence probability, and the influence of weather and climatic events (Adger, 2006). The IPCC Third Assessment Report (TAR) defines vulnerability as "the degree to which a system is susceptible to, or unable to cope with, adverse effects of climate change, including climate variability and extremes. Vulnerability is also a function of the character, magnitude, and rate of climate variation to which a system is exposed, its sensitivity, and its adaptive capacity" (Berrouet et al., 2018). Similarly, Tariq and Giesen (2012) defined vulnerability as the state resulting from the physical, economic, social, and environmental issues of processes that increase the defencelessness of a society to the effects of hazards. The perception of vulnerability is also applied to several research arenas such as disaster-management, environmental, and development studies. The concept of vulnerability is still indistinct (Berrouet et al., 2018; Frick-Trzebitzky et al., 2017; Huq, 2017; Vu and Ranzi, 2017). Authors such as Azad et al. (2013) stated that vulnerability is multidimensional and differential (differing across the physical and social space), subject to scale (time, space, and units, for instance, individual, household, and community), and dynamic (vulnerability features and factors vary over time).

Indexes might also become powerful tools to synthesise vulnerability and risk. Index-based models have gradually been recognised because of their capacity for spatially synthesising stereophonic concepts of vulnerability. The Hyogo Framework for Action 2005-2015 (HFA) called to identify risk and vulnerability indicators, and the consequent application of the results to inform decision makers. From the beginning of the HFA, in addition to the ongoing Sendai Framework for Disaster Risk Reduction (SFDRR) 2015-2030, index-based measure- 
ments are employed in several circumstances and on various scales (UNISDR, 2005). However, there are several appropriate index-based eminent vulnerability approaches that explicitly reflect vulnerability entities, such as the world-risk index, index for risk management, disaster-risk index, and social vulnerability index (SoVI), flood-vulnerability index, and the environmental-vulnerability index (Adnan et al., 2020; Rygel et al., 2006). However, there is an absence of evaluating household vulnerability and comparing slum and non-slum vulnerability levels. Thus, this study provides a foundation with exploratory evidence to reflect theoretical and methodological choices with index-based householdvulnerability assessments for slum and non-slum inhabitants.

\subsection{Flood-vulnerability factors}

The Hamburg University of Technology (2012) noted six vulnerability factors, namely, poverty, equity, livelihood, gender, cultural beliefs, and socialworker groups. The UNESCO-IHE (UNESCO-IHE, 2017) defined vulnerability as comprising three factors (resilience, exposure, and susceptibility) that are responsible for creating flood vulnerability. Existing studies (Adger, 2006; Ahsan and Warner, 2014; Azad et al., 2013; Balica et al., 2012; Barua et al., 2016; Berrouet et al., 2018; Frick-Trzebitzky et al., 2017; Huq and Hossain, 2012; Huq and Hossain, 2015) identified and demonstrated several factors of flood vulnerability. Moreover, previous studies (Adger, 2006; Ahsan and Warner, 2014; Azad et al., 2013; Yamani et al., 2016) demonstrated that social, economic, institutional, structural, environmental, and demographic factors are simultaneously responsible for creating household flood vulnerability. Figure 1 shows vulnerability factors that are influenced by four main components.

These components (social, economic, environmental, and structural) accelerate the flood-vulnerability system. Understanding and identifying vulnerability factors is important (Parvin and Johnson, 2015). Corresponding measurable variables cover the structural, economic, educational, social, cultural, political, institutional, environmental, and ideological dimensions (Schneiderbauer and Ehrlich, 2006). All of these vulnerability characteristics could be related with natural hazards, and especially flood hazards (Queste et al., 2006). However, the vulnerability factors mentioned above are interconnected (Fig. 1). Economic vulnerability leads to social vulnerability (Ahsan and Warner, 2014; Huq et al., 2020). Alternatively, the impact of social vulnerability causes demographic and institutional vulnerability. It is also partially responsible for creating physical and environmental vulnerability.

\subsection{Defining slum and non-slum}

The expansion of slums certainly has significant consequences for both the human and the physical environment. Existing circumstances in slums, for instance, living within physical risk to natural and artificial disasters and fragile 


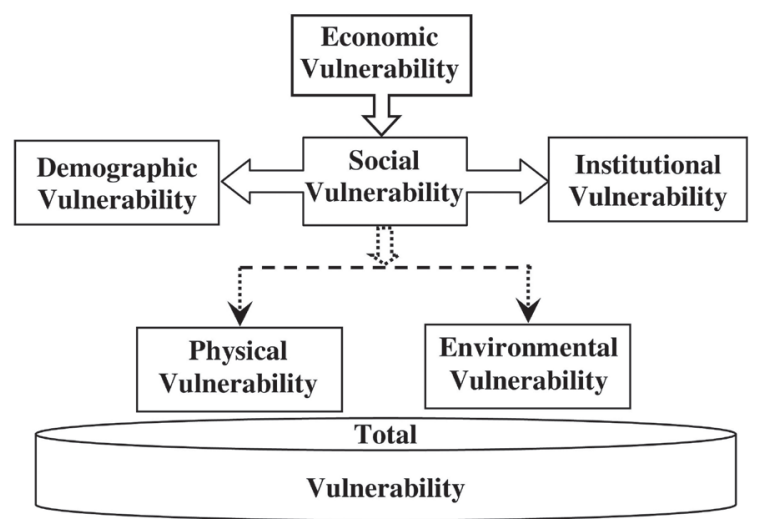

Figure 1. Interconnection of vulnerability factors.

housing conditions directly affects their residents (Bardhan et al., 2018). This is mostly due to the low capacity of slum dwellers to recover from disasters (floods or earthquakes) compared to non-slum residents. Slum residents themselves influence their environment, contaminating soil, air, and water channels (Braun and Aßheuer, 2011). This results in a continued cycle for the declination of living conditions in slums and the natural environment, with possible influences spreading to communities beyond slums (e.g., flooding). The coping capacity of slum people is not in good condition, but non-slum people can cope with floods more easily than slum people.

Usually, slum and non-slum settlements are distinguished on the basis of socioeconomic indicators. However, concerns are being developed that the terminology "slum" is an emotive and pejorative (Huq and Hossain, 2012). The United Nations has mentioned in sustainable-development goals (SDGs) that informal settlements and slums are not synonyms. The most commonly used definition of slum is by the United Nations Human Settlements Programme (UN-HABITAT): "a group of individuals that live under the same roof that lack one or more of the following conditions: access to improved water, access to improved sanitation, sufficient living space, durability of housing, and secure tenure" (UN-HABITAT, 2003). The Bangladesh Slum Areas and Floating Population census in 1997 defined slum to be a group of dense settlements with five and/or more households that normally develop very irregularly and haphazardly in unhygienic conditions and environments on government- or privateowned vacant land (Barua et al., 2016; Kamruzzaman et al., 2020). Slums can also exist in owner-based household locations. The authors in (CUS, 2006) reported that slums are explained as settlements including at least ten households with predominantly very low-quality housing, highly populated and with crowded rooms, few environmental services, particularly water and sanitation, poor 
socioeconomic conditions, and insufficient security. In the context of Bangladesh, a slum denotes temporal, undeveloped, and unhygienic clustered settlements that are normally situated in open places or besides roads, embankments, or rail lines. The present study considers a slum as a temporal, undeveloped, and unhygienic settlement that holds at least 25 households with very low-standard housing, high population density with room crowding, fewer environmental amenities, specifically water and sanitation, inadequate socioeconomic circumstances, and inadequate possession security. In contrast, non-slum refers to a permanent settlement with high or moderate quality of housing, low or middle population density and room crowding, and the availability of urban amenities such as water, electricity, sanitation, and gas with stable socioeconomic status.

Quality of life (QOL) in the environmental and social-relationship domains of slum is worse, but it has recently been slowly changing. Mental health is worse in non-slums, but still not adequate in slums (Henson et al., 2020). This might be because non-slum people live in a structured and rule-based society. In addition, non-slum people learn not to vent to their indignations, but learn to experience not being able to satisfy their wishes in a limited family environment. In addition, non-slum inhabitants are exposed to stricter cultural structures/frameworks or social pressure than slum inhabitants (Izutsu et al., 2006). This seemed to create differences on various scales. However, slum people have low rates of school enrolment, education, household income, low body weight, but a higher amount of child labour. Infant and under-five mortality level is higher in slums than that in non-slums in Bangladesh. Infant-fatality rate in slums is more than twice higher compared to that in non-slum regions. Moreover, Dhaka slums have an approximately 2.6 times higher under-five death rate than that of non-slum areas (Mberu et al., 2016). Under-five-year-old slum children's nutrition status is also quite lower than that in non-slums. On the other hand, slum inhabitants normally have a lower scope of living with an organised social framework. Behaviour disorders are associated with future asocial personality disorders, and substance-linked disorders and crimes. This might be a mechanism for slum anarchy and crime. Overall, the QOL of slum people is worse than that of nonslum individuals. Interestingly, rarely stated in the literature is that slum inhabitants contribute to the economy by subsidising the middle classes and the business world by supplying low-paid labour. Sometimes, this type of informal services positively influences the country's gross economy.

\subsection{Literature review}

Evaluating flood vulnerability is an important initiative to reduce the disaster-related destruction to the society of city areas. Hence, presently, several studies (Balica et al., 2012; Huq, 2017; Huq and Alam, 2003; Parvin and Johnson, 2015; Paulais, 2012; Shao et al., 2019a) are concentrating to understand cities' vulnerability, including the systematic detection of vulnerable groups and assets at risk (Paulais, 2012), and making much effort to measure human vulnerabil- 
ity on the household level (Duží et al., 2017). Measuring household vulnerability is a useful tool to assess damage resulting from floods. Since the end of the $20^{\text {th }}$ century, the significance of vulnerability in disaster management has become an indispensable feature (Ding et al., 2016; Fu et al., 2017; Li et al., 2019; Ma et al., 2020; Niu et al., 2007; Shao et al., 2019b; Zhang et al., 2019) . A growing number of studies investigated vulnerability to hazards, especially for social vulnerability. Among those, the place-based social-vulnerability index (SoVI) suggested by Cutter et al. (2003) is the most useful. Similarly, Ahsan and Warner (2014) developed a socioeconomic-vulnerability index (SeVI) for coastal Bangladesh for measuring vulnerability caused by climate change. In addition, Balica et al. (2012) introduced a methodology to measure flood vulnerability that is applied to computing flood damage at various spatial levels (e.g., rivers, sub catchments, and urban regions). Schinke et al. (2016) introduced flood-resilience technology (FReT) with geoinformation systems and high-spatial-resolution images to reduce flood risk in Valencia, Spain. They demonstrated that the actual exposition and application level of FReT might function for spatial damage and risk analyses. Ten Brinke et al. (2017) suggested an analytical framework for the evaluation of social-vulnerability indices in the European context. Yamani et al. (2016) developed a vulnerability map for the implementation of predictive flood control models. Geographic-information-system (GIS)-based multicriteria decision analysis (MCDA) was applied to assess flood risk. Tang et al. (2018) established a spatially evident, probable GIS-MCDA method to delineate the potentiality of flood-vulnerable regions in Gucheng county, China. An integrated method to assess flood vulnerability was proposed by Yang et al. (2018). They combined the multicriteria decision method to command preference with similarity for ideal solutions by the Shannon entropy technique to assess flood vulnerability on the city and rural scales through GIS. Similarly, Toosi et al. (2019) used a multicriteria index method for classifying possible flood hazards on the river-basin scale of the Mashhad plain valley in northeast Iran. In this study, seven physical flood-influencing factors (rainfall, drainage-network, soil-erosion, and land-use maps, ASTER DEM, and historical flood events) were used to develop a flood-hazard-index (FHI) map. Very recently, another indexing method was developed from the exposure and disaster-reduction-ability categories of flash floods, with the analytical-hierarchy-process (AHP) method by Xiong et al. (2019). The study assessed vulnerability to flash floods in China with the support-vector-machine (SVM) model. Moreover, using a geographic information system (GIS) along with AHP, Saxena et al. (2013) have constructed a composite vulnerability index (CVI) that integrates geophysical-natural, socioeconomic, and institutional factors. Similarly, Sar et al. (2015) have developed a remote sensing and GIS-based vulnerability model for water logging hazard through AHP in India. However, drawing upon gaps in the existing literatures and vulnerability indexing methods, this study contributes as to identify and measure the factors those are responsible for creating household vulnerability to flood 
hazards with AHP. The AHP originally developed by Saaty (1990) and it is often known as the Saaty method (Coyle, 2004). It is an organised template and technique to deal with complicated decisions, and a user can use it for their own purposes. It helps decision makers to identify the best possible ways to understand problems. However, the strength of this model can be evaluated by the consistency ratio (CR). It has three basic principles, i.e., separation, reasonable judgment, and priority synthesis (Rahman and Saha, 2007). It denotes pairwise comparisons with respect to the element at the next upper hierarchical level (i.e. among variables and indicators). Ratings of the elements are denoted as numbers with the comparison matrix. On this basis, the relative weights of all aspects can be calculated by priority level in the hierarchy. Moreover, AHP is generally applied to a fixed variable weight in the GIS to develop spatial/physical (i.e., landuse and soil) maps in the laboratory. However, this study used AHP to in the real world to quantify household vulnerability.

\section{Materials and methods}

\subsection{Profiling study area}

The present study was conducted in Dhaka, capital and megacity of Bangladesh. The population-growth rate is about 2.5 percent per year. It gained city status in 1998, occupying a total area of only 590 square miles with huge population density (Islam et al., 2013). Dhaka is also identified as the city of slums. The Centre for Urban Studies (CUS, 2006) reported that almost 4966 slum and squat clusters exist in this city, but in 1991 this was 2,156 (CUS, 2006). This indicates the quick and continuous growth of slums and squats in this city. As per CUS (2006), 3.4 million people of Dhaka live in slums and squats. It is located in central Bangladesh and surrounded by several rivers, i.e., the Buriganga in the south, and the Turag and the Balu in the north and the northeast, respectively; the north-eastern part is bounded by the Tongi and the Balu. Floods are therefore not a new phenomenon for Dhaka inhabitants. The elevation of Dhaka is $4 \mathrm{~m}$ from mean sea level. Annual mean precipitation is around 1854 $\mathrm{mm}$ (73.0 in) and mostly occurs during the rainy season (May-September). The city has been facing floods since its early age. Historical data showed that it was heavily flooded in 1787-1788. In that time, streets were inundated, and city inhabitants continued their communication by boats (Hunter, 1877). In 18331834 and 1870, Dhaka and its adjacent areas were again affected by floods. In addition, the floods of the 1950s and 1960s severely affected it (Rizvi, 1969). Major devastating floods in Dhaka occurred in 1954, 1955, 1970, 1974, 1980, 1987, 1988, 1998, 2004, 2007, 2009, 2012, and 2016 because of excessive rainfall and overflow from the adjacent rivers. Among those, the floods of 1988 and 1998 were the most disastrous. The 1998 flood was of utmost severity in consideration of damage and duration. It damaged almost 262,000 houses and roughly 1000 
$\mathrm{km}$ of roads. Water supply with sanitation department, power division (Faisal et al., 1999), and different types of industries were harshly affected. It was estimated that approximately USD 3,000 million were lost as result from the flood of 1998. In addition, this flood killed around 248 people. Dhaka was also flooded in 2004, 2007, 2008, 2012, and 2016 because of intense rain (Huq, 2013; Sciance and Nooner, 2018), but these were not as destructive as 1998. During these floods, several environmental problems, like potable-water shortage, interruption of economic functions, and the occurrence of waterborne diseases hampered the daily activities of city dwellers (Alam and Rabbani, 2007). A major part of greater Dhaka is a moderate-very high flood prone area. Only few parts $(8.04 \%)$ are the least vulnerable to flood hazards. On the other hand, $28.70 \%$ of greater Dhaka is highly vulnerable to flood hazards. The western portion of it is protected with an embankment, but so far there is no dam or dyke in the eastern part to protect from spill over floods of Balu river. Therefore, Ward 3 of eastern Dhaka, located between latitudes $23^{\circ} 39^{\prime}$ and $23^{\circ} 54^{\prime} \mathrm{N}$ and longi-tudes $90^{\circ} 20^{\prime}$ and $90^{\circ} 28^{\prime} \mathrm{E}$ (Fig. 2) was selected for evaluating household flood vulnerability.

\subsection{Data collection}

A household survey was carried out in flood-affected areas (Fig. 2). The settlement was selected on the basis of a three-day workshop with local experts,

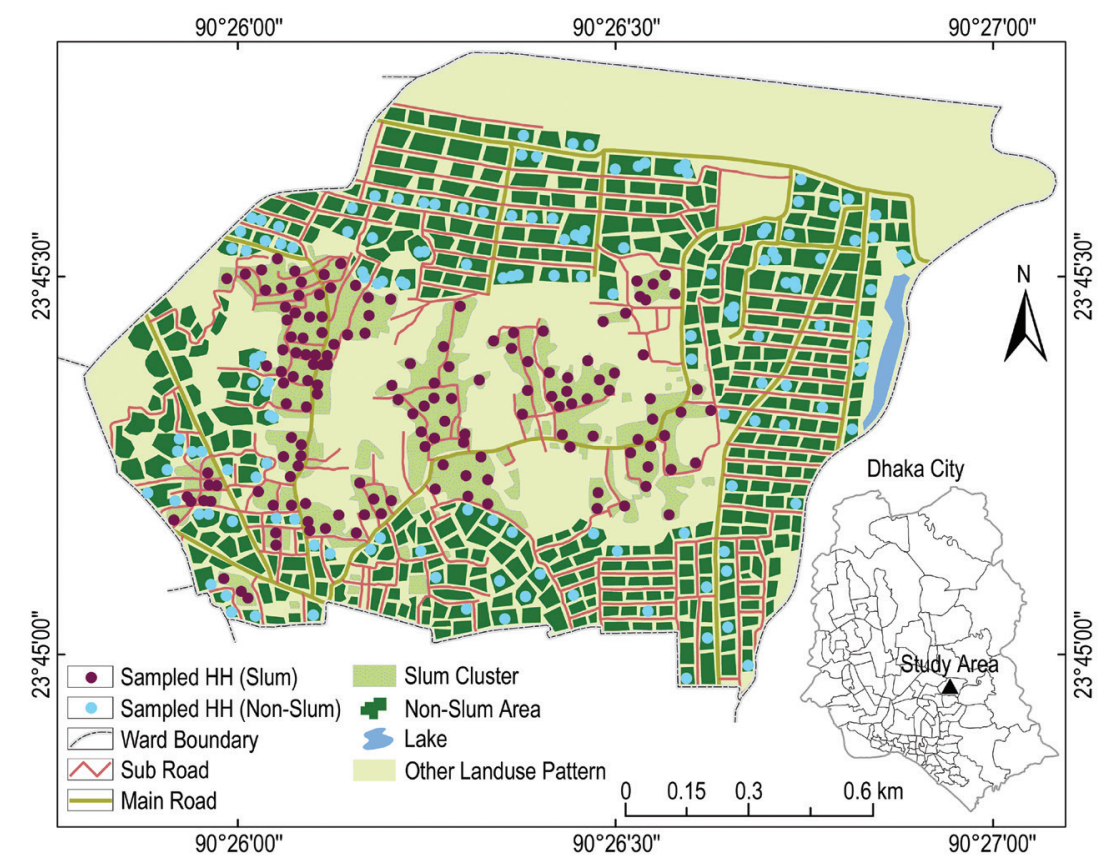

Figure 2. Location of study area with sampled households. 
and a comprehensive field investigation in several Dhaka sites. However, roughly 1900 households exist in this region; among them, 300 (150 non-slum and 150 slum households) were interviewed by questionnaire survey. Households that

Table 1. Model of decision hierarchy for social, economic and structural, institutional and environmental vulnerability.

\begin{tabular}{|c|c|c|c|c|}
\hline & Variables & Weight & Indicators & Weight \\
\hline \multirow{28}{*}{ 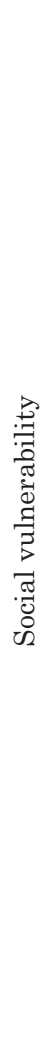 } & \multirow{5}{*}{ Education } & \multirow{5}{*}{0.177} & Illiterate & 0.452 \\
\hline & & & $>1<5$ & 0.215 \\
\hline & & & $>5<10$ & 0.153 \\
\hline & & & $\mathrm{SSC} \& \mathrm{HSC}$ & 0.116 \\
\hline & & & Bachelor/Master & 0.064 \\
\hline & \multirow{7}{*}{ Occupation } & \multirow{7}{*}{0.327} & Unemployment & 0.258 \\
\hline & & & Rickshaw-puller & 0.125 \\
\hline & & & Day-labour & 0.176 \\
\hline & & & Business & 0.058 \\
\hline & & & Housemaid & 0.228 \\
\hline & & & Housewife & 0.122 \\
\hline & & & Service & 0.033 \\
\hline & \multirow{2}{*}{ Household head } & \multirow{2}{*}{0.019} & Male & 0.127 \\
\hline & & & Female & 0.873 \\
\hline & \multirow{4}{*}{ Family size } & \multirow{4}{*}{0.042} & $1-2$ persons & 0.057 \\
\hline & & & $3-4$ persons & 0.122 \\
\hline & & & $5-6$ persons & 0.263 \\
\hline & & & More than 6 & 0.558 \\
\hline & \multirow{2}{*}{ Disabled person } & \multirow{2}{*}{0.116} & Yes & 0.873 \\
\hline & & & No & 0.127 \\
\hline & \multirow{6}{*}{ Social network } & \multirow{6}{*}{0.129} & Relatives (inside Dhaka) & 0.379 \\
\hline & & & Relatives (outside Dhaka) & 0.530 \\
\hline & & & Neighbors & 0.057 \\
\hline & & & Bank & 0.131 \\
\hline & & & NGO & 0.131 \\
\hline & & & Local loan agency & 0.216 \\
\hline & \multirow{2}{*}{ Preparation } & \multirow{2}{*}{0.190} & Yes & 0.170 \\
\hline & & & No & 0.830 \\
\hline \multirow{12}{*}{ 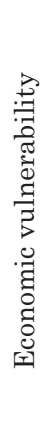 } & \multirow{8}{*}{ Income (USD) } & \multirow{8}{*}{0.356} & Slum; Non-Slum & \\
\hline & & & $40-65 ; 140-200$ & 0.430 \\
\hline & & & $66-90 ; 201-260$ & 0.180 \\
\hline & & & $91-110 ; 261-320$ & 0.140 \\
\hline & & & $111-135 ; 321-380$ & 0.100 \\
\hline & & & $136-160 ; 381-435$ & 0.070 \\
\hline & & & $161-180 ; 436-495$ & 0.050 \\
\hline & & & More than $180 ; 495$ & 0.030 \\
\hline & \multirow{2}{*}{ Land ownership } & \multirow{2}{*}{0.273} & Yes & 0.130 \\
\hline & & & No & 0.870 \\
\hline & \multirow{2}{*}{ Savings } & \multirow{2}{*}{0.093} & Yes & 0.330 \\
\hline & & & No & 0.670 \\
\hline
\end{tabular}


Table 1. Continued.

\begin{tabular}{|c|c|c|c|c|}
\hline & Variables & Weight & Indicators & Weight \\
\hline \multirow{16}{*}{ 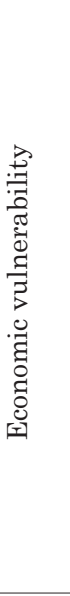 } & \multirow{2}{*}{ Insurance } & \multirow{2}{*}{0.069} & Yes & 0.330 \\
\hline & & & No & 0.670 \\
\hline & \multirow{6}{*}{ Loan status (USD) } & \multirow{6}{*}{0.051} & Slum; Non-Slum & \\
\hline & & & No loan & 0.087 \\
\hline & & & $80-135 ;<1175$ & 0.135 \\
\hline & & & 136-190; 1176-2350 & 0.179 \\
\hline & & & $191-240 ; 2351-3530$ & 0.211 \\
\hline & & & More than $240 ; 3530$ & 0.379 \\
\hline & \multirow{4}{*}{ Ownership of vehicle } & \multirow{4}{*}{0.158} & No vehicle & 0.558 \\
\hline & & & Bi-cycle & 0.264 \\
\hline & & & Motorcycle & 0.121 \\
\hline & & & Private car & 0.056 \\
\hline & \multirow{4}{*}{ Availability of water } & \multirow{4}{*}{0.667} & Filter; Boil + Normal Filter & 0.090 \\
\hline & & & Tap & 0.180 \\
\hline & & & Boil & 0.275 \\
\hline & & & Supply & 0.455 \\
\hline \multirow{5}{*}{ 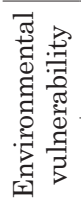 } & \multirow{3}{*}{ Availability of Sanitation } & \multirow{3}{*}{0.333} & No latrine; Single-Pit & 0.441 \\
\hline & & & Communal sanitary latrine; Twin-Pit & 0.324 \\
\hline & & & Hanging; Single + Twin-Pit & 0.235 \\
\hline & \multirow{2}{*}{ Aid in flood } & \multirow{2}{*}{0.750} & Yes & 0.875 \\
\hline & & & No & 0.125 \\
\hline \multirow{7}{*}{ 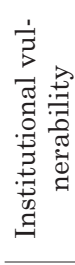 } & \multirow{4}{*}{ Early warning system } & \multirow{4}{*}{0.250} & No & 0.544 \\
\hline & & & 1-3 days before & 0.244 \\
\hline & & & 4-6 days before & 0.136 \\
\hline & & & More than 6 days & 0.076 \\
\hline & \multirow{3}{*}{ Housing type } & \multirow{3}{*}{0.402} & Kutcha & 0.690 \\
\hline & & & Semi-pucca & 0.244 \\
\hline & & & Pucca & 0.066 \\
\hline \multirow{8}{*}{ 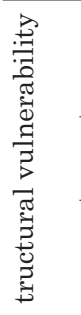 } & \multirow{3}{*}{ Road network } & \multirow{3}{*}{0.232} & Very Bad & 0.688 \\
\hline & & & Bad & 0.234 \\
\hline & & & Good & 0.078 \\
\hline & \multirow{2}{*}{ Shelter in flood } & \multirow{2}{*}{0.305} & Yes & 0.333 \\
\hline & & & No & 0.667 \\
\hline & \multirow{3}{*}{ Transport system } & \multirow{3}{*}{0.061} & Very Bad & 0.688 \\
\hline & & & Bad & 0.234 \\
\hline & & & Good & 0.078 \\
\hline
\end{tabular}

did not face any flood were not included to interview during the survey. Hence, the survey provides a set of samples of households that experienced at least a single severe flood.

A close-ended questionnaire was employed for collecting primary data to measure household vulnerability of flood hazards. Table 1 shows a detailed 
elaboration of indicators with corresponding variables and factors that support the computation of the vulnerability score of a household.

As per hierarchy, factors, variables, and indicators are shown in the first, second, and third order respectively. Accordingly, each factor with total vulnerability was considered as 1 (100\%), which was distributed among its variables. Later, respective variables containing total vulnerability were deliberated as 1 $(100 \%)$, which was disseminated between its different indicators (e.g., literature indicator of education variable corresponding to the factor of social vulnerability).

\subsection{Vulnerability index (VI) computation}

Several techniques were used to develop the vulnerability index (VI) (Ahsan and Warner, 2014; Berrouet et al., 2018; de Leon, 2007; Sebald, 2010). This study attempted to integrate the most suitable method to develop the VI. Figure 3 illustrates the scientific model of vulnerability indexing.

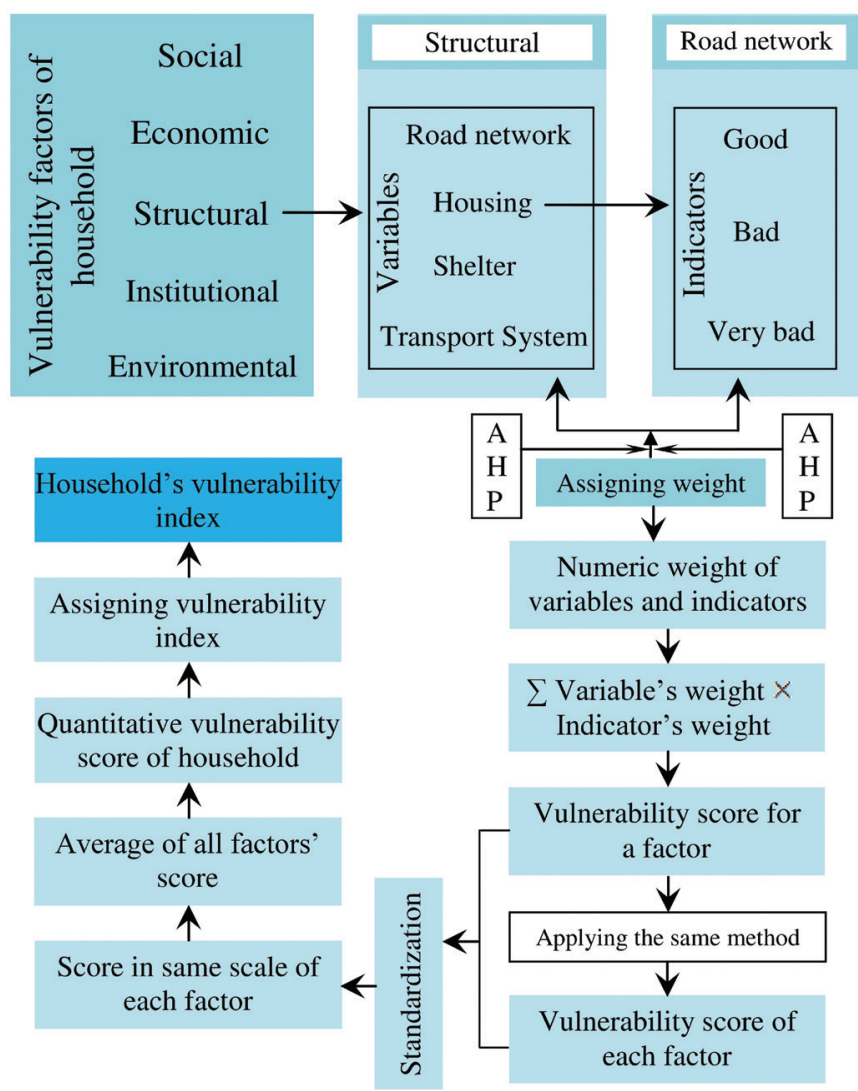

Figure 3. Household vulnerability indexing model. 


\subsubsection{Weighting of variables and indicators}

As previously mentioned, household vulnerability to flood hazards was measured and quantified on the basis of some factors (social, economic, environmental, institutional, and structural vulnerability). Therefore, to assign weight values of variables and indicators, the AHP technique was applied (Saaty, 1990). To identify the comparative importance of variables/indicators, the pairwise judgement method followed. Table 2 exhibits Saaty's pairwise rating scale. Numbers 1-9 were allocated on the importance basis of variables and indicators (Coyle, 2004).

Table 2. Saaty's pairwise rating scale.

\begin{tabular}{|c|c|c|c|c|c|c|}
\hline $\begin{array}{l}\text { Intensity of } \\
\text { importance/level }\end{array}$ & 1 & 3 & 5 & 7 & 9 & $2,4,6,8$ \\
\hline Definition & $\begin{array}{c}\text { Equal } \\
\text { importance }\end{array}$ & $\begin{array}{c}\text { More } \\
\text { important }\end{array}$ & $\begin{array}{l}\text { Much more } \\
\text { important }\end{array}$ & $\begin{array}{c}\text { Very much } \\
\text { more } \\
\text { important }\end{array}$ & $\begin{array}{c}\text { Absolutely } \\
\text { more } \\
\text { important }\end{array}$ & $\begin{array}{c}\text { Intermediate } \\
\text { values }\end{array}$ \\
\hline
\end{tabular}

\subsubsection{Assigning weights}

This section discusses an example deriving weights to a particular indicator. The factor of structural vulnerability was chosen for this example (Tab. 3). There are four variables, namely, housing type $(H T)$, shelter $(S)$, road network $(R N)$, and transport system (TS) that constitute structural vulnerability (Tab. 1). First, it is important to provide an initial matrix for pairwise comparison between variables, as every variable is as important by itself. Then, we considered housing type $(H T)$ to be a more important variable in terms of flood vulnerability than road network $(R N)$ is. So, 3 was assigned in the cell of $(H T, R N)$ and 1/3 in $(R N$, $H T)$. Similarly, it was measured that road network $(R N)$ is much more significant than transport system (TS) to intensify and/or reduce flood disasters. The value of 5 was assigned for the (RN, TS) cell, and of $1 / 5$ for transpose position (TS, $R N)$. Accordingly, housing type (HT) was regarded as much more significant than transport system (TS). The value of 5 was also allocated to (HT, TS), and of $1 / 5$

Table 3. Overall preference matrix with weights of variables.

\begin{tabular}{cccccc}
\hline & $R N$ & $H T$ & $T S$ & $S$ & Weights \\
\hline$R N$ & 1 & $1 / 3$ & 5 & 1 & 0.232 \\
$H T$ & 3 & 1 & 5 & 1 & 0.402 \\
$T S$ & $1 / 5$ & $1 / 5$ & 1 & $1 / 5$ & 0.061 \\
$S$ & 1 & 1 & 5 & 1 & 0.305 \\
\hline \multicolumn{7}{c}{$\mathbf{C R}=\mathbf{0 . 0 7 3}$} \\
\hline
\end{tabular}


to (TS, HT). A similar calculation was done for the variable of shelter $(S)$ with regard to transport system (TS). Lastly, these represent an overall preference matrix $(O P M)$ for structural vulnerability (Tab. 3).

From this $O P M$, the weight of correspondence criterion was calculated by normalising column cells (division of cell value by sum of the column). The average value of normalised cells of the row was considered as the weight of that criterion. However, the consistency of comparisons was considered by calculating consistency ratio $(C R)$. The $C R$ controls the bias of providing weights among each other. Although weights were allocated through field experience, they should neither be over- nor underestimated, but rather be exact as much as possible. The acceptable $C R$ was $<0.10$, and the $C R$ equation is:

$$
C R=\frac{\text { Consistency index }(C I)}{\text { Random index }(R I)} \text {. }
$$

The consistency index $(C I)$ of the matrix was calculated from the following equation:

$$
C I=\frac{\lambda_{\max }-n}{n-1},
$$

where $\lambda_{\max }$ is the highest value (weight) resulting from the $O P M$, and $n$ denotes the number of criteria. The next step follows for calculating $\lambda_{\max }$ as the leading CI. First, we multiplied the right matrix with eigenvector judgments to obtain the new vector. The calculation of the first row of the matrix is as follows:

$$
1 \times 0.232+1 / 3 \times 0.402+5 \times 0.061+1 \times 0.305=0.976
$$

Moreover, the three remaining rows were provided as 1.708, 0.249, and 1.244 , respectively. The AHP model defines that $\lambda_{\max }$ can be estimated with a simple measure of dividing each element $(0.976,1.708,0.249$ and 1.244$)$ with the corresponding weight. This gives $0.976 / 0.232=4.206$ with $4.259,4.22$, and 4.11 . The average of these values $\left(\lambda_{\max }\right)$ is 4.198 . If any estimate for $\lambda_{\max }$ goes out to be less than $n$, or 4 in this case, it confirms an error in calculation. Therefore, the $C I$ of a matrix is (4.198-4) / (4-1) because $n=4$ for the matrix. Lastly, the $C I$ value is 0.066 .

The $R I$ table (Tab. 4), which was developed by Coyle (Saaty, 1990), provides the value of the random index $(R I)$ where the upper row represents the order (value of $n$ ) of the random matrix, and the lower corresponds to $C I$ for random judgments. For this matrix, the $R I$ value was 0.90 because the number of criteria $(n=4)$ is 4 .

Table 4. Random average consistency indexes for various $n$.

\begin{tabular}{cccccccccccc}
\hline$n$ & 1 & 2 & 3 & 4 & 5 & 6 & 7 & 8 & 9 & 10 & 11 \\
\hline$R I$ & 0.00 & 0.00 & 0.58 & 0.90 & 1.12 & 1.24 & 1.32 & 1.41 & 1.45 & 1.49 & 1.51 \\
\hline
\end{tabular}


For this example, $C R$ is $0.066 / 0.90=0.073$. Saaty (Saaty, 1990) claimed that $\mathrm{CR}>0.1$ specifies that all judgments are within the consistency limit.

\subsubsection{Calculating vulnerability score}

This study follows de Leon's equation (de Leon, 2007) for calculating the vulnerability score. The equation is:

$$
\text { Vunerability score }=\Sigma(\text { Variable's weight } \times \text { Indicator's weight })
$$

Table 5 reveals an example of the result for vulnerability score for structural factors by utilising the empirical data of a household. The values in bold of the indicators were used in the calculation.

Table 5. Matrix for calculating structural vulnerability.

\begin{tabular}{lclll}
\hline Variables & Variables' weights & \multicolumn{3}{c}{ Indicators and their weights } \\
\hline \multirow{2}{*}{ Housing type $(H S)$} & \multirow{2}{*}{0.402} & Pucca (built) & Semi-pucca & Kutcha \\
& & 0.066 & 0.244 & 0.690 \\
Shelter $(S)$ & \multirow{2}{*}{0.305} & Yes & No & \\
& & 0.333 & 0.667 & \\
Road network $(R N)$ & \multirow{2}{*}{0.232} & Good & Bad & Very bad \\
& & 0.078 & 0.234 & 0.688 \\
Transport system (TS) & \multirow{2}{*}{0.061} & Good & Bad & Very bad \\
& & 0.078 & 0.234 & 0.688 \\
\hline
\end{tabular}

On the basis of Tab. 5, the score of structural vulnerability of a household is obtained as

$$
\begin{aligned}
V_{\text {score }} & =(0.402 \times 0.690)+(0.305 \times 0.333)+(0.232 \times 0.688)+(0.061 \times 0.688) \\
& =0.278+0.102+0.159+0.042=0.581
\end{aligned}
$$

Using the same technique, the vulnerability scores of all households were calculated. The standard scaling system of Rahman and Saha (Rahman and Saha, 2007) was adopted for making a standard index of vulnerability. Vulnerability scale 1-100 was considered to classify the household-vulnerability level (Tab. 6). A higher value denotes high, and lower value represents low flood vulnerability. However, Eq. (4) was used to calculate the scale:

$$
S_{v c}=\frac{I H_{v c}}{H_{v c}} \times 100,
$$

where, $S_{v c}=$ standardised vulnerability score of a household; $I H_{v c}=$ individual household's vulnerability score; and $H_{v c}=$ highest vulnerability score among total households. 
Table 6. Scale for vulnerability index.

\begin{tabular}{cc}
\hline Range of vulnerability score & Degree of vulnerability \\
\hline $1-35$ & Low \\
$36-70$ & Moderate \\
$71-100$ & High \\
\hline
\end{tabular}

Therefore, the structural vulnerability of Household 001 is as follows:

$$
\begin{gathered}
S_{v c}=\frac{0.581}{0.772} \times 100, \\
S_{v c}=75.25 .
\end{gathered}
$$

The above-mentioned method was applied to each household (150 for slum and 150 for non-slum households) to individually obtain the vulnerability and standardised vulnerability scores. In a similar way, the vulnerabilities of each of the four other factors (social, economic, environmental, and institutional) with respective households were calculated.

Having calculated all factors' vulnerability score, the next step is to aggregate factor score for overall vulnerability index. To realise overall vulnerability, the average of all factors' vulnerability level of total slum and non-slum households was tailored from Sebald (2010). Table 6 shows the degree of vulnerability index based on total vulnerability score. The circumstances were categorised into three levels: low, moderate, and high. Low vulnerability refers to households that are in good situation and not much exposed to flood hazards. This category was in the range of 1-35 in VI. This group is not at risk and is much less vulnerable to potential flood hazards. Moderate or medium vulnerability reveals that households are between low and high vulnerability, which falls between 36 and 70 in $V I$. The high-vulnerability category (71-100) presents high exposure to flood hazards, and the possibility of disaster occurring at an alarming level (Tab. 6).

\subsubsection{Methods for overall indexing and vulnerability mapping}

A normalisation function (Eq. 5) was used to rearrange the factors' vulnerability score of $0-100$ to between 0 to 1 :

$$
\text { Normalized output }=\frac{\text { Input }- \text { Minimal value }}{\text { Maximal value }- \text { Minimal value }},
$$

where the lowest output value is 0 , and the highest output value is 1 . First, this normalisation function was applied to all five factors. Then the median value to their respective factors was used to shift the output away from 0 (Eq. 6).

$$
\text { Update variable }=\text { normalized variable }+ \text { median of variable }
$$


Therefore, all factors had a central tendency near to 1. At this point, all factors were multiplied to form an overall vulnerability index. The index was again normalised, multiplied by 100 to obtain an output of between 0 to 100 .

\section{Results}

\subsection{Structural-vulnerability degree}

Structural vulnerability is an important significant factor to increase or decrease household vulnerability to flood hazards (Samanta et al., 2018). Previous studies (Yamani et al., 2016) showed very few variables to determine structural vulnerability. Housing type, road network, the existence of evacuation roads, drainage systems, flood dams, and geographical location are most widely used among them. Structural vulnerability includes basic constructional conditions of the houses where people live. Naturally, slum inhabitants live in poorer conditions than those of non-slum people. However, this study measures adversity or vulnerability in respect to housing structures. Under structural factors, four variables (types of housing, availability of emergency shelters in flood incidents, and road and transportation systems to evacuate) were included. Analytical results exhibited that most slum households were highly vulnerable (82\%) in consideration to structural factors, and 18\% showed moderate vulnerability. Thus, slum dwellers search for emergency shelters during natural hazards, for instance, floods. Surprisingly, with regard to structural vulnerability, almost all (95.3\%) non-slum households are moderately vulnerable, and very few are highly vulnerable (4.7\%), but there were no low-vulnerable households (Fig. 4a). Moreover, there is an informal relation between inhabitants of poor structured slums and affluent people in built-up rich areas. As women of slum areas often work in affluent areas as maidservants from dawn to dusk, both parties benefit in a symbiotic way, and occasionally share their sorrows and happiness. How-
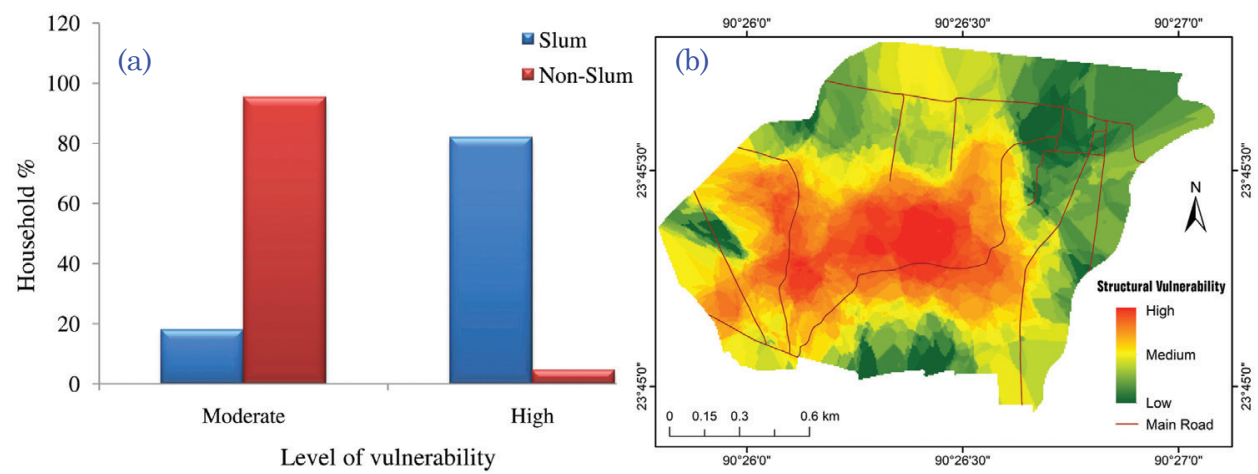

Figure 4. (a) Status of the structural vulnerability of urban people to flood. (b) Spatial distribution of the structural vulnerability. 
ever, Fig. 4b also exhibits the level of structural vulnerability. It shows that inhabitants of the central part, where slum people of the study area live, are highly vulnerable. The inhabitants of peripheral areas are moderately vulnerable to flood hazards.

\subsection{Social-vulnerability degree}

Social vulnerability is mostly visible after a hazard event (Cutter et al., 2003; Tapsell et al., 2010). The nature of social vulnerability depends on the character and magnitude of the hazard. Specific features of a social system can make a particular group more vulnerable (Ahsan and Warner, 2014). Social factors are considered to assess the social status and social vulnerability of slum and nonslum people. The present study incorporated education, household-head mode, the presence of disabled persons, occupation, family size, preparation, and social networks as social factors (Tab. 1). The vulnerability score of all these variables was separately analysed through the AHP process, and then aggregated as mentioned in the methodology section. Figure 5a reveals the total condition of social vulnerability. Results revealed that the combined social vulnerability of slum households/dwellers leads in the moderate-vulnerability category (67.3\%), and little is distributed in low- (16\%) and highly (16.7\%) vulnerable categories. The situation is reverse in non-slum regions, as $78.7 \%$ households are marked as low-vulnerable. and some (18.7\%) were moderately vulnerable. In addition, a small number of households (2.7\%) were highly vulnerable (Fig. 5a). This demonstrates that slum dwellers are neither low-vulnerable nor high, but they live in moderate socially vulnerable conditions if flood hazards would occur. In addition, Fig. 5b shows that the residents of two clusters (central and eastern part) of the area are socially highly vulnerable. North-eastern, western-periphery, and southwestern-cluster inhabitants are low-vulnerable to flood hazards. The vul-

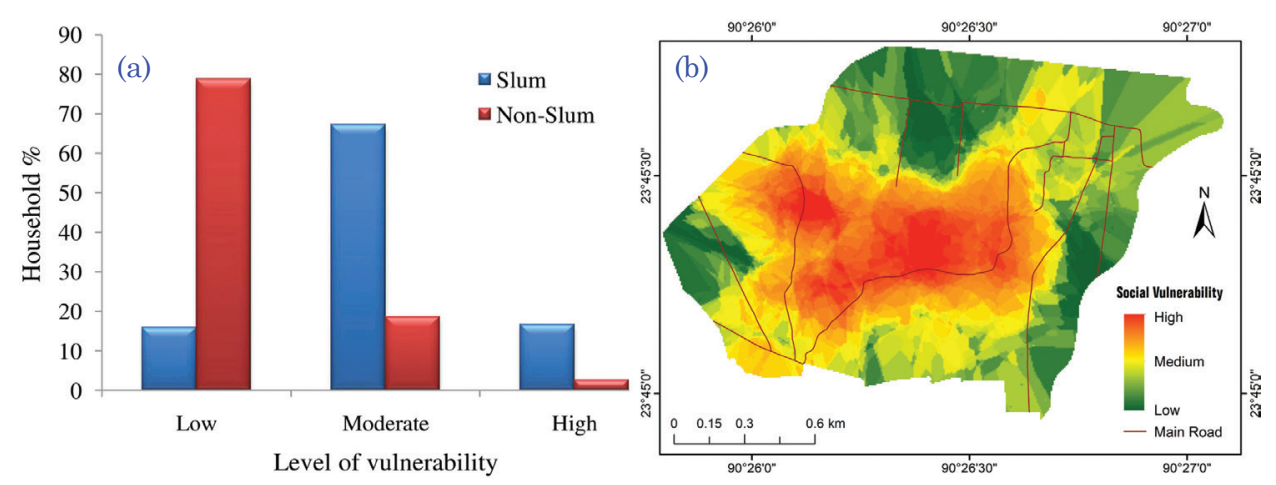

Figure 5. (a) Social vulnerability of urban people to flood. (b) Level of social vulnerability in the study area. 
nerability map shows that most people of the study area are low and moderately vulnerable.

\subsection{Economic-vulnerability degree}

Economic factor is a sensitive determinant to evaluate the situation of vulnerability of slum and non-slum inhabitants. Economic vulnerability is a set of indicators (degree of dependence, diversification deficiency, and share of modern services) (Pilli-Sihvola et al., 2018). Income, employment, health, house, and flood insurance, and savings have a great role in elevating or reducing vulnerability to any kinds (natural and artificial) of hazards or disasters (Queste et al., 2006). Here, household income, land ownership, savings, any kind of insurance, state of loans, and vehicle ownership were counted for measuring economic vulnerability. It is an important factor for obtaining actual knowledge about economic capacity for tackling hardships from potential disasters. The current study found that $84 \%$ of slum households were highly economically vulnerable, and the remaining $16 \%$ were moderately vulnerable. However, in non-slums, the situation is the reverse, with over half (59.3\%) of non-slum households being moderately and $26.7 \%$ highly vulnerable to future floods (Fig. 6a). The remaining $14 \%$ of households were low-vulnerable owing to their durable economic conditions. Economic vulnerability is also shown in Fig. 6b. The households of southwestern and south-eastern parts are low-vulnerable. Moderately vulnerable households are almost evenly distributed in the study area. It is evident that the economic capacity of slum people is relatively fragile to smoothly lead life and combat disasters. Therefore, the government needs to highly prioritise minimising the economic vulnerability of slum dwellers by improving their economic conditions.
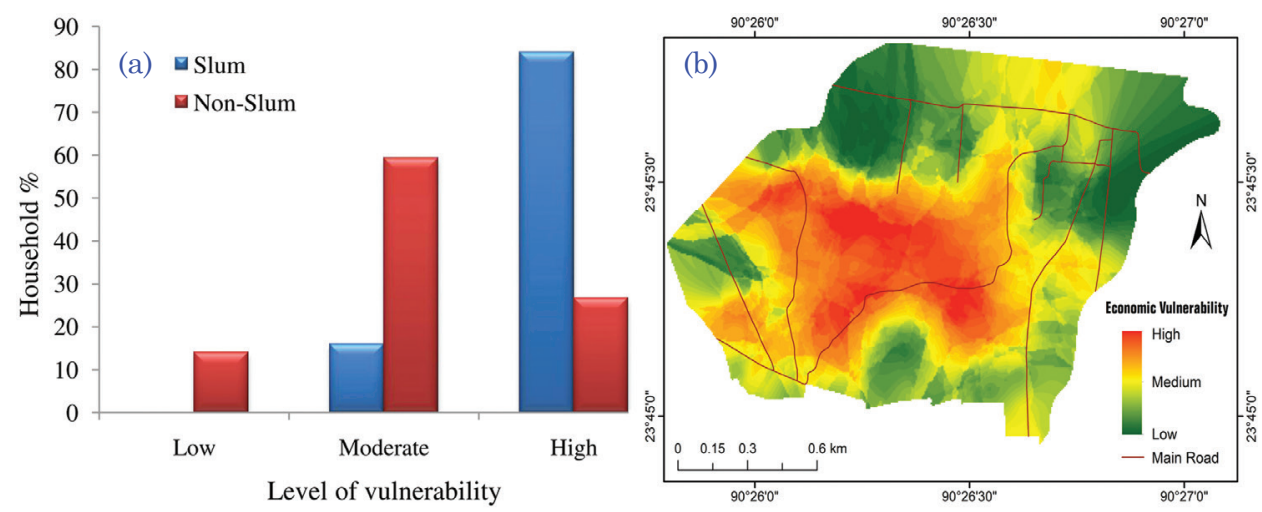

Figure 6. (a) Degree of economic vulnerability of urban people to flood. (b) Distribution of economic vulnerability. 


\subsection{Institutional-vulnerability degree}

Institutional infrastructure offers the capacity to mitigate disaster, and enhances preparedness and response actions (Adger, 2006; Frick-Trzebitzky et al., 2017). It might affect the vulnerability of households and societies by different ways. A lack of early-warning systems, emergency services, and governance can amplify the vulnerability of a household or a community (Pilli-Sihvola et al., 2018). Vulnerability of both slum and non-slum residents is measured with respect to institutional support systems. Institutional support is related to what facilities people receive from government or nongovernmental organisations (NGOs). For this factor, there were two measured variables (aid during flood and forecasting). However, during and after floods, aid comes from governmental and

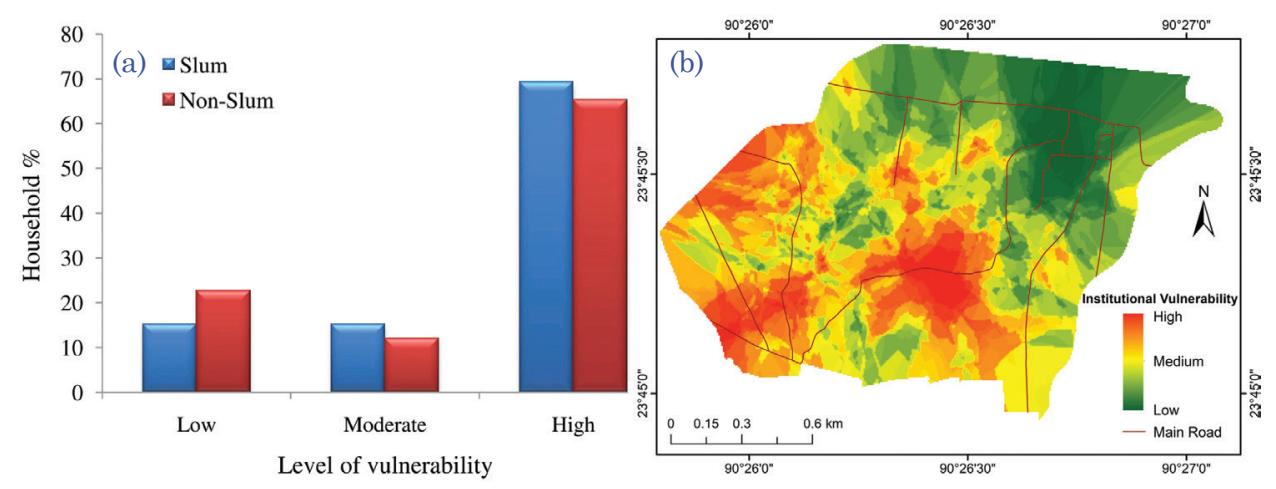

Figure 7. (a) Institutional vulnerability of urban people to flood. (b) Distribution of instructional vulnerability in the study area.

nongovernmental institutions, but governmental organisation is responsible for providing flood forecasts. The observed results represent that most slum (69.3\%) and non-slum (65.3\%) households revealed high vulnerability due to a lack of institutional assistance. Only $15.3 \%$ slum and $12 \%$ non-slum households are moderately exposed, while $15.3 \%$ and $22.7 \%$ households were low-vulnerable with regard to institutional vulnerability (Fig. 7a). Fig. $7 \mathrm{~b}$ reveals that most areas are moderately to highly vulnerable due to institutional facilities, but the north-eastern part is low-vulnerable.

\subsection{Environmental-vulnerability degree}

The present situation of environmental deterioration is a relevant factor to evaluate household vulnerability to floods, droughts, and cyclones. The consequences of environmental degradation may differ with climatic circumstances. Environmental conditions cannot be isolated from social and economic conditions concerning the mutual relationship between the social and natural environment 

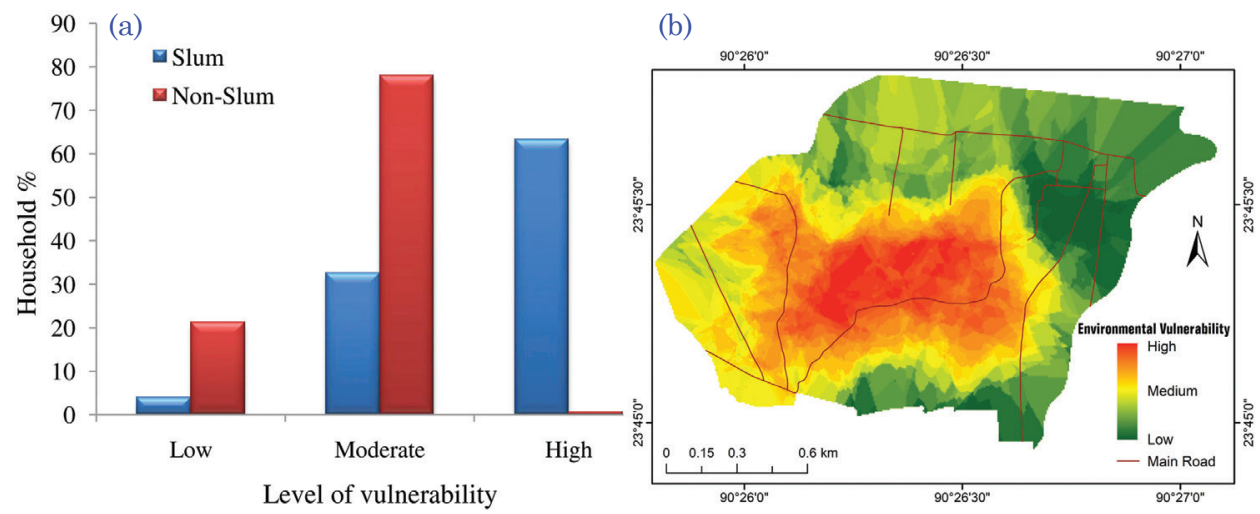

Figure 8. (a) Degree of environmental vulnerability of urban people to flood. (b) Distribution of environmental vulnerability in the study area.

(Cardona, 2011; Samanta et al., 2018). Several existing vulnerability frameworks incorporated environmental components. The direct influence of key resources (such as water and soil) and environmental degradation increase the vulnerability of these communities (Cardona, 2011). Moreover, the location and accessibility of potable water have great importance in determining vulnerability (Parvin and Johnson, 2015).

In urban slums, environmental vulnerability is quite remarkable. Slum dwellers have little access to pure drinking water, clean sanitation, and hygienic toilet facilities. Their way of living raises environmental pollution and vulnerability. This study selected only two variables (availability of potable water and toilet accessibility) considered for evaluating environmental vulnerability for slum and non-slum people. However, raw or no sanitarytoilets spread bad odours that damage people's health and pollute the surrounding environment. On the other hand, drinking-water scarcity is not part of a healthy environment. Empirical results showed that, among slum dwellers, $63.3 \%$ of households were highly vulnerable with regard to environmental circumstances, and the remaining $32.7 \%$ and $4.0 \%$ were moderately and low-vulnerable. This scenario is the reverse in non-slum areas. About $0.7 \%$ non-slum households were highly, $21.3 \%$ moderately, and 78\% low-vulnerable in terms of environmental vulnerability (Fig. 8a). Most areas are moderately vulnerable to flood hazard, but people of the central part are highly vulnerable. Only south-eastern residents are low-vulnerable (Fig. 8b).

\section{Discussions}

\subsection{Assessment method}

Vulnerability-measuring techniques vary on the basis of explanation, theoretical framework, factors, variables, and indicators. In this study, AHP was 
employed to assign weight values of variables and indicators for measuring the household flood vulnerability in Dhaka, Bangladesh. The proposed householdvulnerability indexing model may extend to further inclusive measurement of flood vulnerability, including physical exposure, susceptibility, and coping capability. Compared with earlier models, the AHP method shows less human influence and covers content. Moreover, the application of extensive household-vulnerability measurement to floods can more precisely and locally recognise the pattern of vulnerable populations to floods in Bangladesh. Furthermore, in the present study, the ethics of classification, comparison, and local applicability of a quantitative household-vulnerability measurement and indexing system was established on the basis of primary data. However, the other factor (i.e., flood density) that contributes to measuring vulnerability was region-specific. Flood density describes the number of flood occurrences per unit of area. This rate indirectly recommends flood frequency to evaluate units. In addition, relief-fund allocation depends mostly on disaster intensity and damage. Thus, it is recommended that this method can help to measure household vulnerability in a given local area.

\subsection{Household flood-hazard vulnerability of Dhaka inhabitants}

For evaluating overall flood vulnerability, intensity and frequency of flood hazards (Hung et al., 2016), producing vulnerability map of floods, exposure and disaster-risk reduction (Tapsell et al., 2010) were underlined in previous studies. Within the context of floods, household-vulnerability patterns can assist disaster managers in distinguishing communities with vulnerable populations, inferior abilities to response, and less capacity to reduce disaster risk. Thus, a rapid response is essential during flood events to vulnerable households, and specific attention is needed in the course of disaster inhibition and mitigation (Paulais, 2012). Not only are flood events responsible for occurring flood disasters, but socioeconomic, structural, institutional setup, and environmental conditions also influence them.

In the study area, the majority of households of slum areas were structurally very highly vulnerable to future floods. Empirical data showed that the housing condition of slum residents is too poor. It is obvious that fragile housing types make slum dwellers more vulnerable to floods. Uneven road networks and poor transport services make both slum and non-slum people vulnerable to floods. However, the educational level of slum people is far better than that of non-slum people. Owing to low educational quality, most slum dwellers are either working as daily labourers or rickshaw pullers, so they cannot switch over their occupations in disastrous situations. Most non-slum habitants are engaged with a formal profession, while few slum dwellers are involved with a formal sector. The majority of slum dwellers are not conscious and prepared to tackle any kinds of misfortune. So, slum people are ahead of non-slum people for sudden flood hazards. The social bonding of slum dwellers is much better than that of non-slum habitants. The present study demonstrates that most slum inhabitants are so- 
cially highly vulnerable, but very few non-slum inhabitants are socially highly vulnerable to floods.

Economic factors have a dominating role for generating people's vulnerability to flood hazards. The study showed that the majority of households of the slum community are economically very highly vulnerable due to their low income. Low-pay job make slum dwellers more vulnerable to flash floods and other kinds of hazards or disasters than non-slum people. Therefore, the government needs to highly prioritise minimising the economic vulnerability of slum dwellers by improving their economic conditions. The present study also revealed that slum and non-slum people are very highly vulnerable to flood hazards due to low institutional facility. Remarkably, the institutional vulnerability of both households is almost similar because the inhabitants of both areas live under an institutional framework. They consider this issue virtually useless for their regular life over prioritising economic factors.

For humans, the environment has great importance, but it seems that slum inhabitants live in environmentally risky areas, and the government needs to put many efforts to remove environmental vulnerability. At the same time, it is true that not only is the government is responsible for such environmental misery, but slum dwellers also have the responsibility to keep their surroundings clean. Environmental pollution is the product of both inhabitants themselves and government negligence. Sometimes, slum dwellers use hanging toilets that can easily be affected by floods. As a result, they might be threatened by water pollution. In addition, due to toilet damage, slum dwellers' defecate in floodwater, which is harmful to human health. Slum dwellers might easily be affected by contaminated floodwater in terms of sanitation facilities. In contrast, non-slum habitants are environmentally more secure.

However, the goal of the study is evaluating the overall flood vulnerability of urban people, which represents the level of people's vulnerability to flood hazards in Dhaka. Overall household vulnerability to future floods was developed with

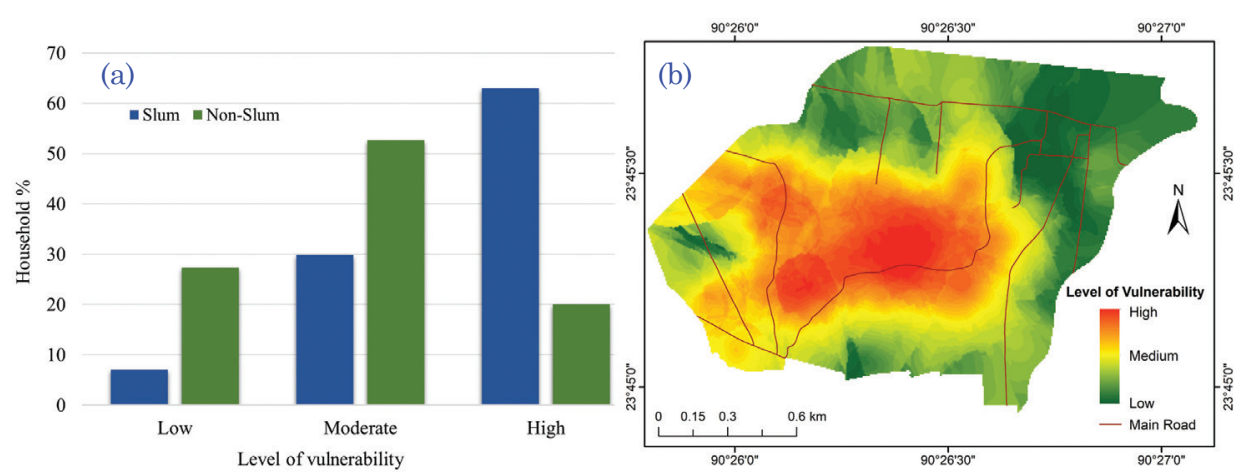

Figure 9. (a) Overall household vulnerability of urban people to flood. (b) Overall vulnerability map of the study area. 
the aggregation of all vulnerability factors (Sebald, 2010). The result showed that the majority of slum $(63.06 \%)$ and $20.02 \%$ of non-slum households are highly vulnerable to floods. Additionally, 29.88\% slum households are moderately and $7.06 \%$ are low-vulnerable. Alternatively, $52.66 \%$ non-slum households were moderately and $27.34 \%$ lowly vulnerable to future floods (Fig. 9a). In addition, Fig. 9b shows that inhabitants of the central part the study area are highly vulnerable. The majority of people of this area are moderately vulnerable. North-eastern residents are low-vulnerable to future floods. The vulnerability maps were deriving from household survey data and created in fixed spatial scaling of vulnerability. Thus, it does not denote individual characteristics of inhabitants.

\subsection{Implications of proposed approach}

This approach could be applied for appraising the consequences of a hazard or guidelines in reproducing index values with contributing variables and indicators. The present study combined indigenous knowledge, expertise, and the AHP to identify and evaluate variables and indicators, and then integrated them. After that, it was applied for measuring household flood vulnerability in Dhaka city. The application of VI creates a platform to assess location-specific vulnerability. The VI approach of this study could be applied for assessing the efficiency of the current disaster-risk-reduction (DRR) programme or policy in Dhaka by reconsidering the indexed values of influencing vulnerability factors, variables, and indicators. For instance, if the purpose of DRR is to improve the knowledge of households to understand early hazard warnings, and a number of disaster-management training programmes are conducted in disaster-prone areas over a specified time period, then on the basis of the situation of the given areas, a new VI hazard score might be gained. Afterwards, the new VI can be compared with the baseline of the proposed VI to measure household vulnerability to disasters. Moreover, the consequence of future multi-hazards of vulnerability may also be measured with the VI by synthesising the number of hazards (e.g., cyclones, floods, and droughts). Furthermore, contributing factors, variables, and indicators of the selection technique and weighing process of VI can be modified to meet the requirements of a specified community. Moreover, sensitive analysis is possible by changing some of the influencing factors within different values (e.g., social, economic, institutional, structural, environmental, demographic, geographical, political, cultural, and ideological) with this method. Even considering some variables (the income of informal households) over time factors could also be measured with the VI to generate spatial variation. With such assessment, policy makers could choose their most favourable approaches in policy formulation for DRR to reduce flood risk. The methodology of selecting responsible factors, variables, and indicators in conjunction with the weighing procedure of VI might modify indexing the vulnerability of a specific community or region. This process of vulnerability indexing is a simple but effective tool to find and evaluate the vulnerability scenario of a disaster-prone area. 
The concept of vulnerability is very complex. There are several international declarations that emphasised the significance of developing indicators for measuring vulnerability and coping capacity to enhance disaster preparation and promote more disaster-resilient societies. Similarly, local to global assistance and progress, and user-friendly DRR technologies with lessons learned from policies, plans, guidelines, and measures of DRR are needed. Regarding this, the constant encouragement of public and private stakeholders is required to effectively engage in DRR schemes, and create new methods to efficiently address DRR strategies locally, nationally, regionally, and globally. However, the results of the present study might help to identify the causes of floods in Dhaka and their impact on the people of adjacent areas. National planning documents have not adequately addressed strategies, policies, and programmes to reduce flood vulnerability in slum and non-slum areas. It is necessary to recognise how vulnerability is originated and increased. This study made it facile to understand household flood vulnerability, and revealed the decision-making process to reduce flood vulnerability and efficiently manage flood disasters. It might help to improve the capability of decision makers on the regional and country level for measuring the key components of disaster risk with vulnerability. This study would also help to improve disaster-risk-reduction systems. The outcome of this study is useful for planners and decision makers to develop a plan for DRR and flood vulnerability in Dhaka. It is easily understandable that slum dwellers are certainly more vulnerable, i.e., more exposed to hazards than non-slum dwellers are in all aspects. However, particular attention was given to measuring household vulnerability to flood hazards for Dhaka inhabitants by scientifically assigning weights on the concerned factors, variables, and indicators. Therefore, the proposed model/method can be greatly applied to identify vulnerable households to flood hazards, and take measures for sustainable development.

\subsection{Study limitations}

Though there are some uncertainties to measure vulnerability, the proposed model/method of this study could measure household vulnerability with the level of vulnerability results from floods. Flood inhibition and mitigation need to be emphasised in Dhaka. There are two types of floods (river flooding, and annual and urban floods) that occur in Dhaka. In this study, only river flooding/annual flood was considered. Disaster management deals with four phases (preparedness, response, recovery, and mitigation), but the present study discussed only two parts (preparedness and mitigation) of those phases. Hazard mitigation and vulnerability reduction often need action on a greater spatial scale than that for people who are explicitly affected. However, the present study is limited to only flood-vulnerable areas. In the present study, the cultural contexts of vulnerability assessments and the dynamic nature of vulnerability were not included. For evaluating household vulnerability to flood hazard, only 21 variables were used. Many other variables could not be applied in this study owing to data unavailability. 


\section{Conclusion}

This study evaluated the vulnerability conditions of slum and non-slum people in Dhaka by longitudinal investigation on households' response to flood effects. Moreover, to reveal the real picture of urban inhabitants, the present study made a comparison study between slum and non-slum inhabitants that showed the potential vulnerability of both types of dwellers. It is useful for decision and policy makers to take necessary initiatives to reduce the vulnerability of slum populations in the case of any type of crisis. Results revealed that the proposed vulnerability index is a very simple but efficient approach to assess household vulnerability to flood hazards. Empirical results confirmed that the majority (63.06\%) of slum households exhibited high vulnerability to flood hazards, while $52.66 \%$ of non-slum households showed moderate vulnerability to future flood events. The research also revealed that the social network of slum dwellers is better than that of non-slum inhabitants. The specification of the study is twofold: first, field data were employed for developing the vulnerability index; second, AHP was applied for assigning weights to the variables and indicators. Using relevant contributing factors and the stepwise weighting approach of the variables and indicators make the vulnerability index more applicable for quantitatively assessing human vulnerability. However, flood vulnerability in the city region is directed by social factors. In this study, demographic vulnerability was not incorporated. Hence, the incorporation of variables and indicators of demographic criteria may provide a better reflection of flood-vulnerability status. Nonetheless, the method of vulnerability index is an effective tool for policy makers to formulate strategies for dealing with flood hazards. This approach was applied to Dhaka, Bangladesh; however, it is also possible to globally extend it to cities with similar characteristics, particularly in developing nations.

Acknowledgements - The research work was supported as the part of National key R \& D plan on the strategic international scientific as well as technological innovation cooperation especial project under Grant 2016YFE0202300, National Natural Science Foundation of China under Grants 61671332, 41771452, 51708426, 41890820 and 41771454, Natural Science Fund of Hubei Province in China under Grant 2018CFA007, the Independent Research Projects of Wuhan University under Grant 2042018kf0250.

\section{References}

Adger, W. N. (2006): Vulnerability, Global Environ. Chang., 16, 268-281, https://doi.org/10.1016/j. gloenvcha.2006.02.006.

Adnan, K. M., Ying, L., Sarker, S., Yu, M., Eliw, M., Sultanuzzaman, M. and Huq, M. E. (2020): Simultaneous adoption of risk management strategies to manage the catastrophic risk of maize farmers in Bangladesh, GeoJournal, 1-18, https://doi.org/10.1007/s10708-020-10154-y.

Ahsan, M. N. and Warner, J. (2014): The socioeconomic vulnerability index: a pragmatic approach for assessing climate change led risks-a case study in the south-western coastal Bangladesh, Int. J. Disast. Risk Re., 8, 32-49, https://doi.org/10.1016/j.ijdrr.2013.12.009.

Alam, M. and Rabbani, M. G. (2007): Vulnerabilities and responses to climate change for Dhaka, Environ. Urban., 19, 81-97, https://doi.org/10.1177/0956247807076911. 
Aliperti, G., Sandholz, S., Hagenlocher, M., Rizzi, F., Frey, M. and Garschagen, M. (2019): Tourism, crisis, disaster: An interdisciplinary approach, Ann. Tourism Res., 79, 102808, https://doi. org/10.1016/j.annals.2019.102808.

Atreya, A., Czajkowski, J., Botzen, W., Bustamante, G., Campbell, K., Collier, B., Ianni, F., Kunreuther, H., Michel-Kerjan, E. and Montgomery, M. (2017): Adoption of flood preparedness actions: A household level study in rural communities in Tabasco, Mexico, Int. J. Disast. Risk Re., 24, 428-438, https://doi.org/10.1016/j.jjdrr.2017.05.025.

Azad, A. K., Hossain, K. M. and Nasreen, M. (2013): Flood-induced vulnerabilities and problems encountered by women in northern Bangladesh, Int. J. Disast. Risk Re., 4, 190-199, https://doi. org/10.1007/s13753-013-0020-z.

Azmeri, Hadihardaja, I. K. and Vadiya, R. (2016): Identification of flash flood hazard zones in mountainous small watershed of Aceh Besar Regency, Aceh Province, Indonesia, Egypt. J. Rem. Sens. Space Sci., 19, 143-160, https://doi.org/10.1016/j.ejrs.2015.11.001.

Balica, S., Wright, N. G. and van der Meulen, F. (2012): A flood vulnerability index for coastal cities and its use in assessing climate change impacts, Nat. Hazards, 64, 73-105, https://doi.org/10.1007/ s11069-012-0234-1.

Bardhan, R., Debnath, R., Malik, J. and Sarkar, A. (2018): Low-income housing layouts under socioarchitectural complexities: A parametric study for sustainable slum rehabilitation, Sustain. Cities Soc., 41, 126-138, https://doi.org/10.1016/j.scs.2018.04.038.

Barua, U., Akther, M. S. and Islam, I. (2016): Flood risk reduction approaches in Dhaka, Bangladesh, in: Urban disasters and resilience in Asia, edited by Shaw, R., Atta, R., Surjan, A. and Parvin, G. A. Butterworth-Heinemann, 209-226.

BBS (2016): Statistical year book of Bangladesh, in: B. Secretariat (Ed.), Dhaka.

Berrouet, L. M., Machado, J. and Villegas-Palacio, C. (2018): Vulnerability of socio-ecological systems: A conceptual framework, Ecol. Indic., 84, 632-647, https://doi.org/10.1016/j.ecolind.2017.07.051.

Blaikie, P., Cannon, T., Davis, I. and Wisner, B. (1994): Disaster pressure and release model, in: At risk: Natural hazards, people's vulnerability, and disasters, 21-45, https://doi.irg/ 10.4324/9780203428764.

Brakenridge, G. R., Syvitski, J. P. M., Niebuhr, E., Overeem, I., Higgins, S. A., Kettner, A. J. and Prades, L. (2017): Design with nature: Causation and avoidance of catastrophic flooding, Myanmar, Earth-Sci. Rev., 165, 81-109, https://doi.org/10.1016/j.earscirev.2016.12.009.

Braun, B. and Aßheuer, T. (2011): Floods in megacity environments: vulnerability and coping strategies of slum dwellers in Dhaka/Bangladesh, Nat. Hazards, 58, 771-787, https://doi.org/10.1007/ s11069-011-9752-5.

Cardona, O. D. (2011): Disaster risk and vulnerability: Concepts and measurement of human and environmental insecurity, in: Coping with global environmental change, disasters and security: Threats, challenges, vulnerabilities and risks, edited by Brauch, H. G., Oswald Spring, U., Mesjasz, C., Grin, J., Kameri-Mbote, P., Chourou, B., Dunay, P. and Birkmann, J. Springer, Berlin, Heidelberg, 107-121.

Coles, D., Yu, D., Wilby, R. L., Green, D. and Herring, Z. (2017): Beyond 'flood hotspots': Modelling emergency service accessibility during flooding in York, UK, J. Hydrol., 546, 419-436, https://doi. org/10.1016/j.jhydrol.2016.12.013.

Coyle, G. (2004): The analytic hierarchy process (AHP), Practical strategy: Structured tools and techniques.

CRED (2018): Natural disasters 2017, in: (02/07/2018 ed.). Brussels: CRED.

CUS (2006): Slums of urban Bangladesh: Mapping and census 2005 Dhaka, Bangladesh, Centre for Urban Studies.

Cutter, S. L., Boruff, B. J. and Shirley, W. L. (2003): Social vulnerability to environmental hazards, Soc. Sci. Quart., 84, 242-261, https://doi.org/10.1111/1540-6237.8402002.

Dalu, M. T. B., Shackleton, C. M. and Dalu, T. (2017): Influence of land cover, proximity to streams and household topographical location on flooding impact in informal settlements in the Eastern Cape, South Africa, Int. J. Disast. Risk Re., 28, 481-490, https://doi.org/10.1016/j.ijdrr.2017.12.009. 
de Leon, J. C. V. (2007): Vulnerability assessment: The sectoral approach, in: Measuring vulnerability to natural hazards: Towards disaster resilient societies, edited by Birkmann, J. United Nations University Press, 300-315.

Dewan, A. M. (2013): Spatial and temporal distribution of floods, in: Floods in a megacity. Springer, Dordrecht, 103-127.

Ding, L., Shao, Z., Zhang, H., Xu, C. and Wu, D. (2016): A comprehensive evaluation of urban sustainable development in China based on the TOPSIS-Entropy method, Sustainability, 8, 746, https:// doi.org/10.3390/su8080746.

Duží, B., Vikhrov, D., Kelman, I., Stojanov, R. and Juřička, D. (2017): Household measures for river flood risk reduction in the Czech Republic, J. Flood Risk Manag., 10, 253-66, https://doi.org/10.1111/ jfr3.12132.

EM-DAT (2014): The OFDA/CRED international disaster database. Université Catholique.

Faisal, I., Kabir, M. and Nishat, A. (1999): Non-structural flood mitigation measures for Dhaka City, Urban Water, 1, 145-153, https://doi.org/10.1016/S1462-0758(00)00004-2.

Frick-Trzebitzky, F., Baghel, R. and Bruns, A. (2017): Institutional bricolage and the production of vulnerability to floods in an urbanising delta in Accra, Int. J. Disast. Risk Re., 26, 57-68, https:// doi.org/10.1016/j.ijdrr.2017.09.030.

Fu, H., Shao, Z., Fu, P. and Cheng, Q. (2017): The dynamic analysis between urban nighttime economy and urbanization using the DMSP/OLS nighttime light data in China from 1992 to 2012, Remote Sens., 9, 416, https://doi.org/10.3390/rs9050416.

Guha-Sapir, D., Hoyois, P., Wallemacq, P. and Below, R. (2016): Annual disaster statistical review 2016: The numbers and trends. Brussels-Centre for Research on the Epidemiology of Disasters, available at https://www.emdat.be/sites/default/files/adsr_2016.pdf.

Halgamuge, M. N. and Nirmalathas, A. (2017): Analysis of large flood events: Based on flood data during 1985-2016 in Australia and India, Int. J. Disast. Risk Re., 24, 1-11, https://doi.org/10.1016/j. ijdrr.2017.05.011.

The Hamburg University of Technology (2012): Flood Manager E-learning, 2012.

Hooke, J. M. (2016): Geomorphological impacts of an extreme flood in SE Spain, Geomorphology, 263, 19-38, https://doi.org/10.1016/j.geomorph.2016.03.021.

Huang, D., Zhang, R., Huo, Z., Mao, F., Youhao, E. and Zheng, W. (2012): An assessment of multidimensional flood vulnerability at the provincial scale in China based on the DEA method, Nat. Hazards, 64, 1575-1586, https://doi.org/10.1007/s11069-012-0323-1.

Hung, L. S., Wang, C. and Yarnal, B. (2016): Vulnerability of families and households to natural hazards: A case study of storm surge flooding in Sarasota County, Florida, Appl. Geogr., 76, 184-197, https://doi.org/10.1016/j.apgeog.2016.09.021.

Hunter, W. W. (1877): A statistical account of Bengal (Vol. 20): Trübner \& Company.

Huq, M. E. (2013): Flood hazard, vulnerability and adaptation of slum dwellers in Dhaka. Germany: Lambert Academic Publishing.

Huq, M. E. (2017): Analyzing vulnerability to flood hazard of urban people: Evidences from Dhaka megacity, Bangladesh, International Journal of Earth Sciences and Engineering, 10, 585-594, https://doi.org/10.21276/ijee.2017.10.0317.

Huq, M. E. and Hossain, M. A. (2012): Flood hazard and vulnerability of slum dwellers in Dhaka, Stanford J. Environ. Human Habitat, 1, 36-47.

Huq, M. E. and Hossain, M. A. (2015): Vulnerability framework for flood disaster management, The Journal of Geo-Environment, 11, 51-67.

Huq, M. E., Shoeb, A. Z. M., Javed, A., Shao, Z., Hossain, M. A. and Sarven, M. S. (2020): Measuring vulnerability for city dwellers exposed to flood hazard: A case study of Dhaka City, Bangladesh, International Conference on Urban Intelligence and Applications, 207-215.

Huq, S. and Alam, M. (2003): Flood vulnerability of Dhaka City and its management, in: Building safer cities: The futures of disaster risk, edited by Kreimer, A., Arnold, M. and Carlin, A. The World Bank, Washington DC, 121-145. 
Islam, M. S., Swapan, M. S. H. and Haque, S. M. (2013): Disaster risk index: How far should it take account of local attributes?, Int. J. Disast. Risk Re., 3, 76-87, https://doi.org/10.1016/j. ijdrr.2012.10.001.

Izutsu, T., Tsutsumi, A., Islam, A. M., Kato, S., Wakai, S. and Kurita, H. (2006): Mental health, quality of life, and nutritional status of adolescents in Dhaka, Bangladesh: Comparison between an urban slum and a non-slum area, Soc. Sci. Med., 63, 1477-1488, https://doi.org/10.1016/j. socscimed.2006.04.013.

Kamruzzaman, M. M., Alanazi, S. A., Alruwaili, M., Alshammari, N., Siddiqi, M. H. and Huq, M. H. (2020): Water resource evaluation and identifying groundwater potential zones in arid area using remote sensing and geographic information system, J. Comput. Sci., 16, 266-279, https://doi. org/10.3844/jcssp.2020.266.279.

Khlopov, O. A. (2019): Cooperative approaches to global environmental problems, Int. J. Prof. Sci., 8, $37-42$.

Li, D., Ma, J., Cheng, T., van Genderen, J. and Shao, Z. (2019): Challenges and opportunities for the development of megacities, Int. J. Digit. Earth, 12, 1382-1395, https://doi.org/10.1080/17538947. 2018.1512662.

Ligon, E. and Schechter, L. (2003): Measuring vulnerability, Econ. J., 113 (486), C95-C102, https:// doi.org/10.1111/1468-0297.00117.

Ma, J., Li, D., Huq, M. E. and Cheng, Q. (2020): Remote sensing detection and impact analysis of Tibetan human landscape in Jiuzhaigou, Int. Arch. Photogramm., 42, 629-633, https://doi. org/10.5194/isprs-archives-XLII-3-W10-629-2020.

Mberu, B. U., Haregu, T. N., Kyobutungi, C. and Ezeh, A. C. (2016): Health and health-related indicators in slum, rural, and urban communities: A comparative analysis, Global Health Action, $\mathbf{9}$ (1), 33163, https://doi.org/10.3402/gha.v9.33163.

Montané, A., Buffin-Bélanger, T., Vinet, F. and Vento, O. (2017): Mappings extreme floods with numerical floodplain models (NFM) in France, Appl. Geogr., 80, 15-22, https://doi.org/https://doi. org/10.1016/j.apgeog.2017.01.002.

Nakanishi, H. and Black, J. (2018): Implicit and explicit knowledge in flood evacuations with a case study of Takamatsu, Japan, Int. J. Disast. Risk Re., 28, 788-797, https://doi.org/10.1016/j. ijdrr.2018.02.008.

Nayyer, S., Huq, M. E., Nana Yaw Danquah, T., Akib, J. and Asif, S. (2019): Parameters derived from and/or used with Digital Elevation Models (DEMs) for landslide susceptibility mapping and landslide risk assessment: A review, ISPRS Int. J. Geo-Inf., 8, 545, https://doi.org/10.3390/ijgi8120545.

Niu, R., Zhang, L., Shao, Z. and Chang, Q. (2007): Web-based geological hazard monitoring in the three gorges area of China, Photogramm. Eng. Rem. S., 73, 709-719, https://doi.org/10.14358/ PERS.73.6.709.

Parvin, A. and Johnson, C. (2015): Disaster vulnerability in the policy context of Bangladesh: A critical review, in: Handbook of Climate Change Adaptation, edited by Filho, W. L. Springer, Berlin, Heidelberg, 877-899.

Pattison-Williams, J. K., Pomeroy, J. W., Badiou, P. and Gabor, S. (2018): Wetlands, flood control and ecosystem services in the Smith Creek drainage basin: A case study in Saskatchewan, Canada, Ecol. Econ., 147, 36-47, https://doi.org/10.1016/j.ecolecon.2017.12.026.

Paulais, T. (2012): Urban risk assessments: An approach for understanding disaster and climate risk in cities, World Bank Publications.

Pilli-Sihvola, K., Harjanne, A. and Haavisto, R. (2018): Adaptation by the least vulnerable: Managing climate and disaster risks in Finland, Int. J. Disast. Risk Re., 31, 1266-1275, https://doi. org/10.1016/j.ijdrr.2017.12.004.

Queste, A., Lauwe, P. and Birkmann, J. (2006): User needs: Why we need indicators, in: Measuring vulnerability to natural hazards: Towards disaster resilient societies, edited by Birkmann, J. United Nations University Press, 103-114.

Rahaman, K. R. (2018): Social Capital and Good Governance-A Nexus for Disaster Management: Lessons Learned from Bangladesh, in: Living under the threat of earthquakes: Short and long-term 
management of earthquake risks and damage prevention in Nepal, edited by Kruhl, J. H., Adhikari, R. and Dorka, U. E. Springer International Publishing, Cham, 211-228.

Rahman, M. R. and Saha, S. (2007): Flood hazard zonation - A GIS aided multi-criteria evaluation (MCE) approach with remotely sensed data, Int. J. Geoinf, 3, 25-37.

Rizvi, S. (1969): East Pakistan District Gazetteers: Dacca (Vol. 1): East Pakistan Government Press. Rygel, L., O'sullivan, D. and Yarnal, B. (2006): A method for constructing a social vulnerability index: an application to hurricane storm surges in a developed country, Mitig. Adapt. Strat. Gl., 11, 741-764, https://doi.org/10.1007/s11027-006-0265-6.

Saaty, T. L. (1990): How to make a decision: The analytic hierarchy process, Eur. J. Oper. Res., 48, 9-26, https://doi.org/10.1016/0377-2217(90)90057-I.

Samanta, R. K., Bhunia, G. S., Shit, P. K. and Pourghasemi, H. R. (2018): Flood susceptibility mapping using geospatial frequency ratio technique: A case study of Subarnarekha River Basin, India, Model. Earth Syst. Environ., 4, 395-408, https://doi.org/10.1007/s40808-018-0427-z.

Sar, N., Chatterjee, S. and Adhikari, M. D. (2015): Integrated remote sensing and GIS based spatial modelling through analytical hierarchy process (AHP) for water logging hazard, vulnerability and risk assessment in Keleghai river basin, India, Model. Earth Syst. Environ., 1, 31, https://doi. org/10.1007/s40808-015-0039-9.

Sarker, M. N. I., Yang, B., Lv, Y., Huq, M. E. and Kamruzzaman, M. M. (2020): Climate change adaptation and resilience through big data, Int. J. Adv. Comput. Sci. Appl., 11, 533-539, https://doi. org/10.14569/IJACSA.2020.0110368.

Schinke, R., Kaidel, A., Golz, S., Naumann, T., López-Gutiérrez, J. S. and Garvin, S. (2016): Analysing the effects of flood-resilience technologies in urban areas using a synthetic model approach, ISPRS Int. J. Geo-Inf., 5, 202, https://doi.org/10.3390/ijgi5110202.

Schneiderbauer, S. and Ehrlich, D. (2006): Social levels and hazard (in)dependence in determining vulnerability, in: Measuring vulnerability to natural hazards: Towards disaster resilient societies, edited by Birkmann, United University Press, 78-102.

Sciance, M. B. and Nooner, S. L. (2018): Decadal flood trends in Bangladesh from extensive hydrographic data, Nat. Hazards, 90, 115-135, https://doi.org/10.1007/s11069-017-3036-7.

Sebald, C. (2010): Towards an integrated flood vulnerability index: A flood vulnerability assessment, unpublished Master of Science thesis.

Shah, A. A., Ye, J., Shaw, R., Ullah, R. and Ali, M. (2020): Factors affecting flood-induced household vulnerability and health risks in Pakistan: The case of Khyber Pakhtunkhwa (KP) Province, Int. J. Disast. Risk Re., 101341, https://doi.org/10.1016/j.ijdrr.2019.101341.

Shao, Z., Ding, L., Li, D., Altan, O., Huq, M. E. and Li, C., (2020): Exploring the relationship between urbanization and ecological environment using remote sensing images and statistical data: A case study in the Yangtze River Delta, China, Sustainability, 12, 5620, https://doi.org/10.3390/ su12145620.

Shao, Z., Fu, H., Li, D., Altan, O. and Cheng, T. (2019a): Remote sensing monitoring of multi-scale watersheds impermeability for urban hydrological evaluation, Remote Sens. Environ., 232, 111338, https://doi.org/10.1016/j.rse.2019.111338.

Shao, Z., Wang, L., Wang, Z. and Deng, J. (2019b): Remote sensing image super-resolution using sparse representation and coupled sparse autoencoder, IEEE J. Sel. Top App., 12, 2663-2674, https://doi.org/10.1109/JSTARS.2019.2925456.

Solín, L., Sládeková Madajová, M. and Michaleje, L. (2018): Vulnerability assessment of households and its possible reflection in flood risk management: The case of the upper Myjava basin, Slovakia, Int. J. Disast. Risk Re., 28, 640-652, https://doi.org/10.1016/j.ijdrr.2018.01.015.

Tang, Z., Zhang, H., Yi, S. and Xiao, Y. (2018): Assessment of flood susceptible areas using spatially explicit, probabilistic multi-criteria decision analysis, J. Hydrol., 558, 144-158, https://doi. org/10.1016/j.jhydrol.2018.01.033.

Tapsell, S., McCarthy, S., Faulkner, H. and Alexander, M. (2010): Social vulnerability to natural hazards. CapHaz-Net WP4 Report. Flood Hazard Research Centre-FHRC, Middlesex University, London, available at: http://citeseerx.ist.psu.edu/viewdoc/download?doi=10.1.1.471.849\&rep=rep $1 \&$ type $=$ pdf (last access: September 2012). 
Tariq, M. A. U. R. and van de Giesen, N. (2012): Floods and flood management in Pakistan, Phys. Chem. Earth, Parts A/B/C, 47-48, 11-20, https://doi.org/10.1016/j.pce.2011.08.014.

Ten Brinke, W. B. M., Knoop, J., Muilwijk, H. and Ligtvoet, W. (2017): Social disruption by flooding, a European perspective, Int. J. Disast. Risk Re., 21, 312-322, https://doi.org/10.1016/j. ijdrr.2017.01.011.

Toosi, S. A., Calbimonte, G. H., Nouri, H. and Alaghmand, S. (2019): River basin-scale flood hazard assessment using a modified multi-criteria decision analysis approach: A case study, J. Hydrol., 574, 660-671, https://doi.org/10.1016/j.jhydrol.2019.04.072.

Turner, B. L., Kasperson, R. E., Matson, P. A., McCarthy, J. J., Corell, R. W., Christensen, L., Eckley, N., Kasperson, J. X., Luers, A. and Martello, M. L. (2003): A framework for vulnerability analysis in sustainability science, P. Natl. Acad. Sci.-Biol., 100, 8074-8079, https://doi.org/10.1073/ pnas. 1231335100 .

UNESCO-IHE (2017): Flood vulnerability indices (FVI), available at: http://www.unesco-ihe-fvi.org (last access on 05 November 2019).

UN-HABITAT (2003): The challenge of slums: Global report on human settlements, 2003: United Nations Human Settlements Programme.

UNISDR (2005): Hyogo framework for action 2005-2015: Building the resilience of nations and communities to disasters, in: Extract from the final report of the World Conference on Disaster Reduction (A/CONF. 206/6), The United Nations International Strategy for Disaster Reduction Geneva.

UNISDR (2019): 2018: Extreme weather events afected 60 million people.

$\mathrm{Vu}, \mathrm{T}$. T. and Ranzi, R. (2017): Flood risk assessment and coping capacity of floods in central Vietnam, J. Hydro-Environ. Res., 14, 44-60, https://doi.org/10.1016/j.jher.2016.06.001.

Xiong, J., Li, J., Cheng, W., Wang, N. and Guo, L. (2019): A GIS-based support vector machine model for flash flood vulnerability assessment and mapping in China, ISPRS Int. J. Geo-Inf., 8, 297, https://doi.org/10.3390/ijgi8070297.

Yamani, K., Hazzab, A., Sekkoum, M. and Slimane, T. (2016): Mapping of vulnerability of flooded area in arid region. Case study: Area of Ghardaïa-Algeria, Model. Earth Syst. Environ., 2, 147, https://doi.org/10.1007/s40808-016-0183-x.

Yang, W., Xu, K., Lian, J., Ma, C. and Bin, L. (2018): Integrated flood vulnerability assessment approach based on TOPSIS and Shannon entropy methods, Ecol. Indic., 89, 269-280, https://doi. org/10.1016/j.ecolind.2018.02.015.

Zhang, H., Ning, X., Shao, Z. and Wang, H. (2019): Spatiotemporal pattern analysis of china's cities based on high-resolution imagery from 2000 to 2015, ISPRS Int. J. Geo.-Inf., 8, 241, https://doi. org/10.3390/ijgi8050241.

\title{
SAŽETAK
}

\section{Procjena ugroženosti stanovnika grada Dhake s obzirom na izloženost opasnosti od poplave}

\author{
Md. Enamul Huq, Qimin Cheng, Orhan Altan, A. Z. M. Shoeb, \\ Mallik Akram Hossain, Md. Nazirul Islam Sarker, Nayyer Saleem, \\ Akib Javed, Xiaoyi Longg, Ahmed Abdullah Al Dughairi, \\ Md. Masud Parves Rana i Md. Mahabubur Rahman
}

Globalna opasnost od poplave postupno se povećava. Iako ih je nemoguće izbjeći, gubici i šteta od opasnosti (npr. poplave, cikloni i potresi) mogu se učinkovito smanjiti smanjenjem ranjivosti kućanstava odgovarajućim mjerama. Cilj ove studije je kvantitativno mjerenje ranjivosti kućanstava obzirom na opasnosti od poplave kao alata za njihovo ublažavanje. Također je predložen jedinstveni pristup za kvantificiranje ugroženosti 
kućanstava obzirom na opasnosti od poplave, a kao primjer predstavljena je primjena $u$ gradu Dhaki sklonom poplavama. Podaci su prikupljeni i sa siromašnih i bogatih područja kako bi bilo pokriveno cijelo urbano područje te kako bi se usporedila razina ugroženosti od poplava. Ukupno 300 kućanstava anketirano je strukturiranim upitnikom na temelju pet čimbenika (ekonomskih, socijalnih, okolišnih, strukturnih i institucionalnih) ugroženosti od poplava. Analitički hijerarhijski postupak (AHP) primijenjen je za mjerenje pojedinačnih rezultata ranjivosti kućanstva korištenjem relativne težine varijabli i pokazatelja uz pravilnu standardizaciju. Analitički rezultati pokazali su da je 63,06\% siromašnih kućanstava i $20,02 \%$ bogatih kućanstava vrlo osjetljivo na poplave. Uz to, ovaj je rad utvrdio i procijenio čimbenike odgovorne za ranjivost kućanstava u Dhaki. Što se tiče strukturne ranjivosti, rezultati su pokazali da je $82 \%$ kućanstava u siromašnim krajevima bilo visoko ranjivo, a 95,3\% kućanstava koja nisu iz siromašnih četvrti bilo je umjereno ranjivo. Društveno, 67,3\% siromašnih i 78,7\% kućanstava koja nisu iz siromašnih naselja bila su umjereno i slabo ranjiva. Većina kućanstava u siromašnoj i nesiromašnoj četvrti (84\%, odnosno 59,3\%) pokazala je visoku i umjerenu ekonomsku ranjivost. Štoviše, za $69,3 \%$ siromašnih i 65,3\% nesiromašnih kućanstava institucionalna ranjivost je bila visoka. Od stanovnika siromašnih naselja, $63,3 \%$ je bilo izloženo ekološkom riziku, a 78\% staništa koja nisu u siromašnim područjima bilo je u kategoriji niske ranjivosti. Uz odgovarajuću prilagodbu ovdje predložen učinkoviti alat za mjerenje ranjivosti koji je ovdje prilagođen specifičnoj lokaciji, primjenjiv je i za mjerenje ranjivosti drugih gradova $u$ svijetu. Na temelju ove studije moglo bi se provesti buduće istraživanje s više čimbenika, varijabli i pokazatelja ljudske ranjivosti na prirodne ili umjetne opasnosti / katastrofe. Budući rad mogao bi pružiti bolju sliku stanja ranjivosti od pojedinačne / višestruke opasnosti / katastrofe.

Ključne riječi: opasnost od poplave, kvantificiranje ugroženosti, AHP, gradski stanovnici, Bangladeš

Corresponding author's address: Qimin Cheng, School of Electronics Information and Communications, Huazhong University of Science and Technology, 1037 Luoyu Road, Wuhan 430074, China; tel: +86 1354513 4531; e-mail: chengqm@hust.edu.cn 